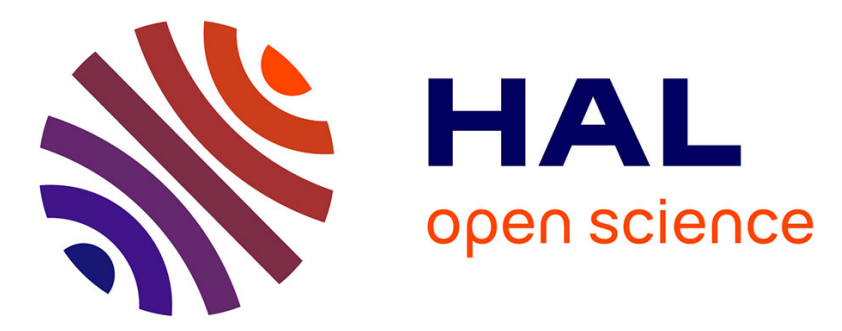

\title{
A Changhsingian (late Permian) nautiloid assemblage from Gujiao, South China.
}

Luyi Miao, Xu Dai, Dieter Korn, Arnaud Brayard, Jing Chen, Xiaokang Liu, Haijun Song

\section{- To cite this version:}

Luyi Miao, Xu Dai, Dieter Korn, Arnaud Brayard, Jing Chen, et al.. A Changhsingian (late Permian) nautiloid assemblage from Gujiao, South China.. Papers in Palaeontology, 2021, 7 (1), pp.329-351. 10.1002/spp2.1275 . hal-03236848

\section{HAL Id: hal-03236848 \\ https://hal.science/hal-03236848}

Submitted on 6 Oct 2021

HAL is a multi-disciplinary open access archive for the deposit and dissemination of scientific research documents, whether they are published or not. The documents may come from teaching and research institutions in France or abroad, or from public or private research centers.
L'archive ouverte pluridisciplinaire HAL, est destinée au dépôt et à la diffusion de documents scientifiques de niveau recherche, publiés ou non, émanant des établissements d'enseignement et de recherche français ou étrangers, des laboratoires publics ou privés. 


\title{
Accepted version of:
}

\section{A Changhsingian (Late Permian) nautiloid assemblage from Gujiao, South China}

Published in Papers in Palaeontology, 2021, 7 (1), 329-351.

Luyi Miao ${ }^{1}, \mathrm{Xu}_{\mathrm{Dai}}{ }^{1}$, Dieter Korn ${ }^{2,3}$, Arnaud Brayard ${ }^{4}$, Jing Chen ${ }^{5}$, Xiaokang Liu ${ }^{1}$ and Haijun Song ${ }^{1, *}$

${ }^{1}$ State Key Laboratory of Biogeology \& Environmental Geology, School of Earth Sciences, China University of Geosciences, 388 Lumo Road, Wuhan, China

${ }^{2}$ Museum für Naturkunde Berlin, Leibniz-Institut für Evolutions- und Biodiversitätsforschung, Invalidenstraße 43, 10115 Berlin, Germany

${ }^{3}$ Nanjing Institute of Geology and Palaeontology, Chinese Academy of Sciences, 39 East Beijing Road, Nanjing, China

${ }^{4}$ Biogéosciences, UMR 6282, CNRS, Université Bourgogne Franche-Comté, 6 Boulevard Gabriel, 21000 Dijon, France

${ }^{5}$ Yifu Museum of China University of Geosciences, 388 Lumo Road, Wuhan, China

*Corresponding author: haijunsong@cug.edu.cn

\begin{abstract}
A ca. $0.30 \mathrm{~m}$ thick cherty limestone bed in the Dalong Formation at Gujiao (Guizhou) yielded a highly diverse Changhsingian nautiloid assemblage. Its age is late Changhsingian, indicated by the co-occurring ammonoid Pseudotirolites sp. This assemblage is composed of nine species and five taxa in open nomenclature in nine genera, including one new genus and three new species:

Neotainoceras zhaoi sp. nov., Nodopleuroceras gujiaoense sp. nov., and Gujiaonautilus longliensis gen. nov., sp. nov. Sholakoceras is for the first time recorded in South China. Compared with literature data from 52 sites in various regions worldwide, the material described here presents the most diverse Changhsingian nautiloid assemblage. Among the genera of the Gujiao assemblage, Pleuronautilus, Tainoceras and Liroceras are cosmopolitan, while the others are more endemic or
\end{abstract}


genera known so far only from South China.

Key words Nautiloidea, Cephalopoda, Permian, Changhsingian, Guizhou, China.

\section{INTRODUCTION}

The greatest Phanerozoic mass extinction at the Permian-Triassic boundary (PTB) extirpated more than $80 \%$ of marine species (Erwin 1994; Song et al. 2013; see last estimates in Stanley 2016). Many groups such as ammonoids (e.g., Villier \& Korn 2004; Brayard et al. 2009), brachiopods (e.g., Shen \& Shi 2002; He et al. 2015), conodonts (e.g., Orchard 2007; Lai et al. 2018), foraminifers (e.g., Groves et al. 2005; Song et al. 2011) and calcareous algae (e.g., Jia \& Song 2018) suffered a significant drop in diversity during the PTB mass extinction. However, timing and pattern of nautiloid extinction during this event and their subsequent recovery are still not well-understood, owing to the relative paucity of reported occurrences and detailed taxonomic, biostratigraphic and phylogenetic studies of this fossil group (e.g., Kummel 1953).

Changhsingian nautiloids are known from various places; they had been reported from the Bellerophon Formation in the Dolomites, North Italy (Posenato \& Prinoth 2004; Prinoth \& Posenato 2007), the Akhura Formation of Armenia and Azerbaijan (Shimansky 1965; Kotlyar et al. 1983), the Ali Bashi Formation of NW Iran (Teichert \& Kummel 1973), the Khuff Formation of Saudi Arabia (Chirat et al. 2006; Posenato 2010), the Chhidru Formation of the Salt Range in Pakistan (Waagen 1879; Reed 1944; Kummel \& Teichert 1970), the Urushten Formation of Psebay, Krasnodarskiy Kray in Russia (Kotlyar et al. 1989), the Takhtabulak of Tajikistan (Shimansky 1992), the Changxing and Dalong formations of South China (Zhao et al. 1978; Liang 1984; Zheng 1984) and the Huai Tak Formation of Thailand (Ishibashi et al. 1994). The nautiloids from these localities can be attributed to ten families, of which the Grypoceratidae, Liroceratidae and Tainoceratidae are dominant.

The earliest report of Lopingian (Late Permian) nautiloids from South China was that of Tainoceras orientale (“Nautilus orientalis") and T. mingshanense ("Nautilus mingshanensis”), described by Kayser (1883) from the Jiangxi Province. After a long interruption, Zhao et al. (1978) illustrated very diverse Changhsingian cephalopod assemblages in their monograph, but they described only a few nautiloids from Anhui, Zhejiang, Guangxi and Guizhou. Following this study, Zheng (1984) investigated a Changhsingian nautiloid assemblage from Guizhou. Liang (1984) 
reported on a few nautiloids from several scattered sections in Hunan and Guangxi. A nautiloid assemblage from a reef environment in Lichuan (Hubei) was studied by Wu \& Kuang (1992). Additional to these occurrences, nautiloid material was mentioned from other places, e.g. Fujian (Yang et al. 1987), Chongqing and Sichuan (Wang 1990).

Here we document a new diverse nautiloid assemblage from the Changhsingian Dalong Formation at the Gujiao section (Guizhou) that corresponds to deeper-water facies. As nautiloids are generally only minor components in the fossil record, this rather rich assemblage may improve our knowledge of the Changhsingian nautiloids not only of South China, but it might also provide important data for future studies on the nautiloid extinction and recovery as well as their evolution at the PTB.

\section{GEOLOGICAL SETTING}

The Gujiao section is located ca. $20 \mathrm{~km}$ south-east of Guiyang, the capital of Guizhou. During the PTB interval, this area had an equatorial position at the interface between the Panthalassa ocean and the Tethys (Fig. 1A). It belonged to the transitional zone between the upper Yangtze Platform and the Nanpanjiang Basin (Feng et al. 1997). The studied section is an outcrop along a new road; it shows well-exposed Permian and Triassic strata ranging from the Late Permian Changxing and Dalong formations to the Early Triassic Daye Formation (Fig. 1B).

The Changxing Formation is composed of bioclastic and cherty limestones. It yielded abundant and diverse Late Permian fossils, e.g. brachiopods, bryozoans, gastropods, corals and dasycladacean algae (Dai et al. 2019). This bioclastic limestone-dominated succession with abundant calcareous algae and corals suggests deposition on a carbonate platform. One volcanic ash bed has a position near the top of the formation (Fig. 1D).

The Dalong Formation consists mainly of cherty limestone, cherts and black shales, which are alternating with volcanic ash beds (Fig. 1D; Dai et al. 2019). Abundant radiolarians were documented in the cherty limestone and cherts, suggesting a deep basin setting (Feng \& Gu 2002). A cherty limestone bed of ca. $30 \mathrm{~cm}$ thickness in the lower part of the Dalong Formation yielded abundant and well-preserved nautiloids $(n=103)$ and ammonoids $(n>300)$. The occurrence of the ammonoid genus Pseudotirolites (Fig. 2) indicates a late Changhsingian age (Dai et al. 2019).

The overlying Triassic Daye Formation is characterized by alternations of thin- to 
medium-bedded limestones and shales corresponding to a basin or basin margin setting. A diverse fauna, including bivalves, nautiloids, gastropods and foraminifers was found in the lower Daye Formation, with several successive ammonoid assemblages indicating an Induan age (Dai et al. 2018, 2019).

\section{MATERIAL AND METHODS}

A total of 103 nautiloid specimens were collected from a single cherty limestone bed with $30 \mathrm{~cm}$ thickness in the lower Dalong Formation (bed 7 in Fig. 1D). Most of the specimens are internal moulds; only some of them possess remnants of the recrystallized shell. Despite of this, they are relatively often well-preserved. This nautiloid assemblage consists of nine species and five taxa in open nomenclature in nine genera: Tainoceras guizhouense Zheng, 1984, Tainoceras sp., Neotainoceras zhaoi sp. nov., Neotainoceras sp. A, Neotainoceras sp. B, Pleuronautilus zhongyingensis Zheng, 1984, Pleuronautilus sp., Nodopleuroceras gujiaoense sp. nov., Gujiaonautilus longliensis gen. nov., sp. nov., Sholakoceras sp., Liroceras lichuanense Wu, 1992, Liroceras orientale Zhao, 1954, Aulagonoceras plicatum Zheng, 1984 and Pseudotitanoceras sp.

All the specimens were prepared in the laboratory using air scribe to work out anatomy details to facilitate species level identification. Well-preserved nautiloid specimens were photographed using a Canon 70D camera with a macro lens EF $100 \mathrm{~mm} \mathrm{f} / 2.8$.

\section{SIGNIFICANCE FOR PALAEOBIOGEOGRAPHY}

Changhsingian nautiloids in South China: a regional signal linked to depth?

Changhsingian nautiloids are abundant and widespread in South China (Zhao et al. 1978; Liang 1984; Zheng 1984; Wu \& Kuang 1992). They were mainly reported from Guizhou, Zhejiang and Hubei and are distributed in three main depositional environments, i.e. reefs, slopes and basin settings. The compositional similarity of the Changhsingian assemblages from Meishan (Zhejiang), Qinglong and Langdai (West Guizhou) is rather high. Material of these three regions was recorded from slope and basinal environments. All these deep or slope-environment sites show relatively similar assemblages with the predominant tainoceratid genera Tainoceras, Neotainoceras and Pleuronautilus. 
Zheng (1984) documented several sections with diverse nautiloids from the deeper-water Dalong Formation in western Guizhou. These assemblages from the Zhongying and Langdai sections are dominated by the families Tainoceratidae (Tainoceras, Neotainoceras, Pleuronautilus) and Trigonoceratidae (Aulagonoceras), accompanied by a few representatives of the Liroceratidae (Liroceras) and Gzheloceratidae (Tylonautilus).

Diverse nautiloids were reported from the Changxing Formation of the Meishan section (slope facies; Zhao et al. 1978). This community is composed of the Tainoceratidae (Tainoceras, Neotainoceras, Pleuronautilus, and Metacoceras), Liroceratidae (Liroceras), and Gzheloceratidae (Parametacoceras).

In contrast to these common assemblages from slope and basin settings, the nautiloids from the Jiantianba reefs in Lichuan (Wu \& Kuang 1992) show a low taxonomic diversity. This assemblage is dominated by Liroceras and Permonautilus and includes nine species in eight genera. Unlike the abundant Tainoceratidae in the deep-water facies of Guizhou and Zhejiang, this family is rather rare and only the single genus Pleuronautilus was found in the Jiantianba reefs.

The taxonomic composition of the Gujiao assemblage is very similar to those from western Guizhou (Langdai and Qinglong). Sholakoceras and the new genus Gujiaonautilus are here described for the first time. The Gujiao nautiloid assemblage is therefore overall congruent with other deep-water Chinese nautiloid faunas, which are dominated by the family Tainoceratidae, and includes only a few genera of the Liroceratidae, Trigonoceratidae, Grypoceratidae, and Rhiphaeoceratidae.

\section{Changhsingian nautiloids in other regions}

Most localities yielding Changhsingian nautiloids are restricted to low Tethyan palaeolatitudes (Fig. 3; Table S1), e.g. Iran (Teichert \& Kummel 1973), Armenia and Azerbaijan (Shimansky 1965; Kotlyar et al. 1983), Italy (Posenato \& Prinoth 2004; Prinoth \& Posenato 2007), Saudi Arabia (Chirat et al. 2006; Posenato 2010), Thailand (Ishibashi et al. 1994). Only the nautiloids from Tajikistan (Shimansky 1992) and Pakistan (Waagen 1879; Reed 1931, 1944; Kummel \& Teichert 1970) are closer to middle palaeolatitudes. Iran, Armenia and Azerbaijan are adjacent regions, so that we combined them into the Transcaucasia-Iran region. The nautiloid composition of the Transcaucasia-Iran region is most similar to that in South China. Nautiloid assemblages from 
Northwest and Central Iran (Teichert \& Kummel 1973; Taraz et al. 1981) contain Metacoceras, Tainoceras, Liroceras, and Pleuronautilus. Shimansky (1965) and Kotlyar et al. (1983) reported several nautiloid assemblages from Transcaucasia (Armenia and Azerbaijan), including Syringonautilus, Tainionautilus, Pleuronautilus, Domatoceras, and Foordiceras. Most of these genera were also documented in South China except Syringonautilus and Temnocheilus.

Another location with abundant nautiloids is the Salt Range Pakistan, which is dominated by Tainoceratidae with a few Grypoceratidae and Koninckioceratidae (Waagen 1879; Reed 1944; Kummel \& Teichert 1970). Most of the nautiloids of the Salt Range were also reported in the Transcaucasia-Iran region, e.g. Metacoceras, Pleuronautilus, Tainionautilus, Tainoceras, Domatoceras, Temnocheilus. Aside from these genera, two representatives of the Grypoceratidae appear to be restricted to the Salt Range, i.e. Stearoceras and Pselioceras (Reed 1944).

The Dolomites in northern Italy are another region with nautiloids in a subequatorial region (Posenato \& Prinoth 2004; Prinoth \& Posenato 2007). However, this community is different from that of the Transcaucasia-Iran basin; it is dominated by the Liroceratidae (Liroceras and Peripetoceras) and Tainoceratidae (Foordiceras, Tirolonautilus and Tainoceras).

Besides these larger nautiloid assemblages, some low-diverse Changhsingian nautiloid occurrences are known from other regions. In the Urushten Formation of Psebay (Krasnodarskiy Kray, Russia), only the two genera Pseudotemnocheilus and Pleuronautilus were reported (Kulikov \& Tkachuk 1979; Kotlyar et al. 1989). Only one genus Tirolonautilus was reported in the Khuff Formation of Ad Dawadimi, central Saudi Arabia (Chirat et al. 2006). In Tajikistan, only the single genus Pararhiphaeoceras was recorded from Changhsingian strata by Shimansky (1992). Only Siamnautilus was documented in the Huai Tak Formation of Thailand by Ishibashi et al. (1994). The nautiloids in Tajikistan and Thailand were all endemic taxa.

\section{SYSTEMATIC PALAEONTOLOGY}

Systematic descriptions mainly follow the classifications proposed by Kummel (1964) and Dzik (1984). Synonymy lists and taxa in open nomenclature are annotated following the recommendations of Matthews (1973) and Bengtson (1988); 'v' implies that the authors have checked the original material of the reference; ' $p$ ' indicates that the reference applies only in part to the species under discussion. The morphological range of each taxon has been quantified using the four classic 
geometrical parameters of the nautiloid conch: diameter (dm), whorl height (wh), whorl width (ww), umbilical diameter (uw) and the distance between two rows of ventral nodes (Dn). Descriptive terminology for the conch morphology is after Korn (2010). All specimens described here are housed in the Yifu Museum of China University of Geosciences, Wuhan, China (YFMCUG 00201YFMCUG 00303).

Further abbreviations are:

NIGPAS - Nanjing Institute of Geology and Palaeontology, Chinese Academy of Sciences $\mathrm{xx}-\mathrm{xx}$

Class CEPHALOPODA Cuvier, 1797

Subclass NAUTILOIDEA Agassiz, 1847

Order NAUTILIDA Agassiz, 1847

Family TAINOCERATIDAE Hyatt, 1883

Genus TAINOCERAS Hyatt, 1883

Type species. Nautilus quadrangulus McChesney, 1860; Pennsylvanian at Grayville, White County (Illinois, United States).

Diagnosis. Tainoceratidae with subinvolute to subevolute conch and subquadrate whorl profile, venter with central groove and sometimes two additional, shallower grooves. Sculpture with a double row of nodes on the venter. Suture line with a narrow ventral lobe in the area of the ventral groove and shallow lateral lobes.

Remarks. Tainoceras is a long-ranging genus from the Gzhelian to the Late Permian. In the Changhsingian, Tainoceras is diverse and widely distributed with at least five valid species (Yao et al. 1980; Zheng 1984; Prinoth \& Posenato 2007). Tainoceras is similar to Metacoceras Hyatt, 1883 (which does not possess a ventral groove), Tirolonautilus Mojsisovics, 1902 (which possesses a depressed to slightly compressed conch with a median ventral groove and occasionally oblique ribs on the venter), Pleuronautilus Mojsisovics, 1882 (which has a smooth venter), and Tainionautilus Mojsisovics, 1902 (which has strongly oblique ribs on flanks and venter). 
Tainoceras guizhouense Zheng, 1984

Figure 4A, B

v. 1984 Tainoceras guizhouense; Zheng, p. 242, pl. 2, figs. 1-5.

Holotype. Specimen NIGPAS 34364; illustrated by Zheng (1984, pl. 2, fig. 5).

Type locality and horizon. Zhongying, Qinglong; Changhsingian.

Material. Only one well-preserved phragmocone (YFMCUG 00201).

Diagnosis. Tainoceras with subevolute conch and subrectangular and depressed whorl profile; broad and arched venter with rounded ventrolateral shoulders; the flanks converge towards the subangular umbilical margin with. Venter with central groove and sometimes two further, shallower grooves. Sculpture with a double row of transversely elongated nodes on both sides of the ventral groove; a row of larger nodes were located on the ventrolateral shoulder and rise to shallow ribs on flanks. Suture line with a narrow external lobe in the area of the ventral groove and broad ventral saddles, broad and shallow lateral lobes on the flank.

Description. Specimen YFMCUG 00201 is $89 \mathrm{~mm}$ in maximum diameter. It is pachyconic and subevolute $(\mathrm{ww} / \mathrm{dm}=0.62 ; \mathrm{uw} / \mathrm{dm}=0.34)$ with subrectangular and moderately depressed whorl profile; the width is much larger than the height $(\mathrm{ww} / \mathrm{wh}=1.56)$. The very broad and slightly convex venter bears a marked central groove; it has a width of $4.7 \mathrm{~mm}$ on the last portion of the phragmocone (at $\mathrm{dm}=89 \mathrm{~mm}$ ). One additional, shallow ventral groove is located on each side at the ventral margin near the rounded ventrolateral shoulder. The flanks converge slowly towards the umbilical margin and the maximum whorl width is located at the ventrolateral shoulder. The umbilicus has a subangular margin and a vertical wall.

The conch bears a very conspicuous sculpture. Two rows of transversely elongated nodes are arranged on both sides of the ventral groove. These ventral nodes are approximately $15 \mathrm{~mm}$ long and spaced regularly $7.5 \mathrm{~mm}$ apart $($ at $\mathrm{dm}=89 \mathrm{~mm}$ ). Another two rows of nodes are located on the 
ventrolateral shoulders; they give rise to shallow ribs that extend across the flanks and disappear near the umbilical shoulder. The umbilical shoulders bear two rows of small and elongated nodes. The suture line shows a narrow, deep ventral lobe in the area of the ventral groove and broad and shallow lateral lobes.

Remarks. Numerous species of Tainoceras have been separated on the basis of differences in the shape and characteristics of sculpture. T. guizhouense is distinguished from almost all other species of the genus by its coarse and elongated nodes and three grooves on the venter. T. unklesbayi Miller \& Youngquist, 1949 from the Early Permian Toroweap Formation of the Grand Canyon is similar to T. guizhouense with its elongated nodes on each side of the ventral groove, but its ventral nodes are obliquely elongate (transversely elongate in T. guizhouense).

Occurrence. Dalong Formation, Guizhou; late Changhsingian. T. guizhouense has so far only been reported from Changhsingian strata of Guizhou (Yao et al. 1980; Zheng 1984).

\section{Tainoceras sp.}

Figure 4C

Description. Only one fragment (YFMCUG 00202) of a phragmocone with weakly depressed subrectangular whorl profile $(\mathrm{ww} / \mathrm{wh}=1.20)$ is available. The venter is arched with a narrow and shallow longitudinal central groove. Two rows of regularly spaced nodes are arranged adjacent to the ventral groove. The angular ventrolateral shoulders show a row of elongated nodes, which are larger than the ventral nodes. The flank converges towards the umbilical shoulder with the maximum width at the ventrolateral shoulders.

Remarks. This specimen exhibits characteristic features of Tainoceras, e.g. the depressed subrectangular whorl profile, two rows of nodes on the venter and two rows of nodes on the ventrolateral shoulders. However, the smooth flanks have never been documented in any species of Tainoceras. Therefore, our specimen might represent a new species. We prefer to keep it in open nomenclature because only one fragment is available. 
Genus Neotainoceras Zhao, Liang \& Zheng, 1978

Type species. Neotainoceras pachydiscum Zhao, Liang \& Zheng, 1978; Meishan (Zhejiang, South China), Changhsingian.

Diagnosis. Tainoceratidae with subevolute conch and depressed subquadrate whorl profile. Slightly arched venter, rounded ventrolateral shoulders, slightly arched flanks converging slowly towards the umbilicus, broadly angular umbilical margin. Prominent ventral groove. The sculpture possesses four rows of ventral nodes and an additional row of nodes on the ventrolateral shoulders. Siphuncle with near-central position. Suture line with shallow and narrow ventral lobes and broad lateral lobes is affected by nodes; it forms saddles in areas of nodes and lobes in grooves.

Remarks. Neotainoceras differs from Tainoceras by the presence of four rows of elongated nodes on the venter. Neotainoceras was introduced by Zhao et al. (1978), including N. pachydiscum from Meishan and N. liuchengense from Liucheng. Subsequently, Zheng (1984) described N. liuchengense and N. gigantum from the Dalong Formation of West Guizhou. Yang et al. (1987) also reported N. xindianziense from the Tiefoshan Formation of Guangyuan, in Sichuan. Neotainoceras has been so far documented only from Changhsingian strata of South China.

Neotainoceras zhaoi sp. nov.

Figures 4D-G, 5A-C

Derivation of name. Named after Zhao Jinke (previously Chao King-Koo), a pioneer cephalopod researcher in China.

Holotype. YFMCUG 00203; illustrated in Fig. 4F.

Paratypes. The five specimens, YFMCUG 00204 (Fig.4D), YFMCUG 00205 (Fig.4E), YFMCUG 00206 (Fig.5A), YFMCUG 00207 (Fig.5B), YFMCUG 00208 (Fig.5C). 
Type locality and horizon. Gujiao section (Guizhou); bed GJ-7 in the Dalong Formation (late Changhsingian).

Material. A total of nine specimens (YFMCUG 00203-YFMCUG 00211) were collected from the type horizon: six well-preserved fragments are included in the type series (YFMCUG 00203-YFMCUG 00208); additionally three internal moulds or squashed fragments.

Diagnosis. Neotainoceras with subinvolute conch and depressed subrectangular whorl profile. Slightly convex venter with narrow ventral groove and rounded ventrolateral shoulders, convex flanks and angular umbilical margin. Sculpture with two rows of elongate ventral nodes symmetrically positioned on both sides of the ventral groove, one row of obtuse nodes on the ventrolateral shoulder, two rows of weak nodes on the flank and one row of elongate and low nodes on the umbilical shoulder. Ventral nodes slightly oblique. Subcentral siphuncle. Suture line with rather deep and narrow lobe at the ventral groove, a shallow rounded lobe as it crosses another groove and a low saddle as it crosses a row of nodes on the ventral area; lateral lobe broad and shallow.

Description. The rather well-preserved holotype (specimen YFMCUG 00203, Fig. 4F) has a maximum diameter of $72 \mathrm{~mm}$. The conch is thinly pachyconic and subinvolute $(\mathrm{ww} / \mathrm{dm}=0.66$; $\mathrm{uw} / \mathrm{dm}=0.29)$ with a weakly depressed subrectangular whorl profile $(\mathrm{ww} / \mathrm{wh}=1.47)$. The venter is broadly arched and bears a narrow ventral groove; it is separated from the convex, almost parallel flanks by a rounded ventrolateral shoulder. The umbilicus is deep with vertical wall and is separated from the flanks by a weakly angular margin. Two rows of blunt ventral nodes are symmetrically located on each side of the ventral groove. These nodes are weakly elongated and slightly oblique. The flanks show two additional rows of low nodes, and the umbilical margin bears one row of rather small and elongated nodes.

The suture line forms a narrow ventral lobe at the central groove, a rather shallow and rounded lobe as it crosses the second groove between the ventral nodes, a small rounded saddle as it crosses a row of nodes and broad and shallow lateral lobes. The siphuncle has a near-central position. 
Remarks. Among the four other species assigned to the genus Neotainoceras, N. pachydiscum closely resembles $N$. zhaoi, but the ventral nodes of $N$. zhaoi are sharper than in N. pachydiscum and other species. Aside from ventral nodes, the flanks of $N$. zhaoi with two rows of nodes differ from other species of Neotainoceras. While the flanks of $N$. pachydiscum and $N$. liuchengense are decorated with a row of small tubercles near the umbilical margin, the flanks of $N$. gigantum are smooth without tubercles. $N$. zhaoi has also a more rectangular whorl profile than $N$. pachydiscum, $N$. liuchengense and N. gigantum. Additionally, N. zhaoi differs from N. gigantum by its narrow ventral groove. $N$. liuchengense has a more depressed whorl profile. The ventral nodes of $N$. xindianziense are more oblique than those of $N$. zhaoi.

Occurrence. Dalong Formation (late Changhsingian); Gujiao section (Guizhou).

\section{Neotainoceras sp. A}

Figure 5D-E

Material. Two poorly preserved internal mould specimens including a fragment (YFMCUG 00212, Fig. 5D) with only the ventral part well visible and an internal mould with fuzzy sculpture (YFMCUG 00213, Fig. 5E).

Description. Specimen YFMCUG 00212 is subevolute $(\mathrm{uw} / \mathrm{dm}=0.39$ at $\mathrm{dm}=47.5 \mathrm{~mm})$ with moderately depressed subrectangular whorl profile $(\mathrm{ww} / \mathrm{wh}=1.63)$. The venter is arched and bears four rows of blunt nodes symmetrically distributed on the venter with the first row of elongate ventral nodes being larger than the second. The ventrolateral shoulder is angular with a row of elongate and larger nodes. The flank, without clear ornamentation preserved, converges towards the umbilical margin with the maximum whorl width at ventrolateral shoulder. The suture line is slightly sinuous on the venter with a shallow and narrow ventral lobe in the central groove.

Remarks. The six rows of nodes on the venter and ventrolateral shoulders are the characteristic feature of Neotainoceras. The ventral nodes of Neotainoceras sp. A are rather smaller than the second row, in this it differs from N. zhaoi, which possesses shaper and larger ventral nodes. 
However, the bad preservation prevents further assignment. Thus, we prefer to keep it in open nomenclature.

Neotainoceras sp. B

Figure 6A

Material. Only one fragment (YFMCUG 00214) with preserved ventral part and a part of the flank.

Description. The slightly arched venter exhibits a broad and deep central groove paralleled by two rows of elongate nodes on each side. The rounded ventrolateral shoulder bears a row of obtuse and rather large nodes. The flank is almost flat with a row of low and small tubercles near the umbilical margin.

Remarks. Neotainoceras sp. B differs from other Neotainoceras representatives in the nodes of the first ventral row, which are longitudinally elongated and blunt, contrary to other species of Neotainoceras.

Genus Pleuronautilus Mojsisovics, 1882

Type species. Pleuronautilus trinodosus Mojsisovics, 1882; Northern Alps (Austria), Anisian.

Diagnosis. Tainoceratidae with subevolute to evolute conch and subquadrate whorl profile. Venter nearly smooth, the flanks possess coarse, straight or slightly sinuous ribs. In most species, the ribs bear one or several spirally arranged nodes. Subcentral siphuncle, suture line with broad ventral and lateral lobes.

Remarks. Pleuronautilus is one of the most diverse genera of the Tainoceratidae. It was a long-living genus, ranging from the Asselian to the Norian (e.g. Dzik 1984). Mojsisovics (1882) erected this genus based on Triassic specimens from Northern Alps. Following this work, Foord (1891) emended Pleuronautilus to include a variety of Permian forms. Arthaber (1896) established more additional species and Hyatt (1900) established the family Pleuronautilidae. However, through multiple 
revisions, Kummel (1953) attributed Pleuronautilus to the Tainoceratidae and added five subgenera (Encoiloceras, Anoploceras, Holconautilus, Enoploceras, Trachynautilus), now regarded as genera, to Pleuronautilus, which altogether contains approximately 95 species. Dzik (1984) discussed the phylogeny of Pleuronautilus and the possibility that it is a polyphyletic taxon composed of several evolutionary lineages that branched independently. More than eight Changhsingian species of Pleuronautilus were reported so far (Waagen 1879; Reed 1944; Shimansky 1965; Zhao et al. 1978; Kulikov \& Tkachuk 1979; Yao et al. 1980; Kotlyar et al. 1983; Zheng 1984). It mainly differs from Anoploceras and Encoiloceras by its compressed whorl profile and from Metacoceras and Mojsvaroceras by the node-bearing ribs on the flanks.

During the last 60 years, Late Permian representatives of Pleuronautilus were sporadically reported from sites that were mainly located in the equatorial area of Tethys. From the Wuchiapingian, numerous Pleuronautilus specimens were discovered in Azerbaijan and NW Iran (Shimansky 1965; Teichert \& Kummel 1973). From South China, Changhsingian material was reported from Zhejiang (Zhao et al. 1978) and Guizhou (Zheng 1984). Pleuronautilus has so far not been recorded from Induan strata immediately after the PT mass extinction, but from the Olenekian, the genus is known from Chernyshev Bay, Russkiy Island, Russia (Zakharov 1978), and Utah (McGowan et al. 2009). Middle and Late Triassic material of Pleuronautilus was rarely documented. Except for undefined species from the late Norian of Nevada (Laws 1982), Vörös (2001) described one Anisian species from Hungary and Jurkovšek et al. (2002) described the Ladinian Pleuronautilus gaudryi from Slovenia.

Pleuronautilus zhongyingensis Zheng, 1984

Figure $7 \mathrm{~A}, \mathrm{~B}$

v. 1984 Pleuronautilus zhongyingensis Zheng, p. 245, pl. 2, figs. 12,13; pl. 3, fig. 1; text-fig. 5.

Holotype. Specimen NIGPAS 34379; illustrated by Zheng (1984, pl. 2, fig. 12-13).

Type locality and horizon. Zhongying section in Qinglong, Guizhou; Dalong Formation (Changhsingian). 
Diagnosis. Pleuronautilus with subevolute conch and depressed subtrapezoidal whorl profile. Venter smooth and arched with subangular ventrolateral shoulders; flanks converge towards the rounded umbilical margin. Sculpture with robust and prorsiradiate ribs on the lateral area. Subcentral siphuncle, suture line with broad ventral and lateral lobes.

Material. Three strongly recrystallized (YFMCUG 00215- YFMCUG 00217) fragments.

Description. Specimen YFMCUG 00215 is subevolute ( $\mathrm{uw} / \mathrm{dm}=0.40$ at $81 \mathrm{~mm}$ diameter) and has a subtrapezoidal, weakly depressed whorl profile $(\mathrm{ww} / \mathrm{wh}=1.21)$ with a smooth venter and a subangular ventrolateral shoulder. The flanks are slightly convex and convergent towards the umbilical margin; the maximum whorl width is at the ventrolateral shoulder. They are ornamented with robust and prorsiradiate ribs, becoming wider towards the ventrolateral shoulder. The umbilicus has a vertical wall and a rounded umbilical shoulder. The suture line is not visible.

Remarks. Our specimens are perfectly fitting with the Changhsingian specimens of Pleuronautilus zhongyingensis described and illustrated by Zheng (1984) from the Zhongying section of Qinglong, West Guizhou. Wu \& Kuang (1992) found Pleuronautilus cf. zhongyingensis in a Changhsingian reef at Lichuan. When comparing the material of the two sites, it is obvious that the ribs of the holotype of P. zhongyingensis are coarser. P. changxingensis Zhao et al. (1978) from the Changxing Formation of Meishan section differs from P. zhongyingensis by the presence of prorsiradiate ribs on the flanks and a wider umbilicus.

Occurrence. Dalong Formation (late Changhsingian) of the Jianzishan and Zhongying sections, South China (Zheng 1984).

Pleuronautilus sp.

Figure $7 \mathrm{C}-\mathrm{G}$

Material. Seven specimens (YFMCUG 00218-YFMCUG 00224). 
Description. The best-preserved specimen YFMCUG 00220 (Fig. 7F, G) has a maximum diameter of $50 \mathrm{~mm}$ and is thinly discoidal and subevolute $(\mathrm{ww} / \mathrm{dm}=0.34 ; \mathrm{uw} / \mathrm{dm}=0.42)$ with an almost quadratic whorl profile $(\mathrm{ww} / \mathrm{wh}=1.01)$ and a subtabulate venter. The convex flanks converge slowly towards the rounded ventrolateral shoulder; the maximum whorl width is near the rounded umbilical margin. The umbilical wall is vertical. The flanks are ornamented with dense, rectiradiate ribs starting from the umbilical margin and disappearing at the ventrolateral shoulder. The suture line has a broad shallow ventral lobe and broad lateral lobes.

Remarks. Compared with other Late Permian material of Pleuronautilus, the ribs of these specimens are more closely arranged and gracile. The similar Changhsingian species P. magnus (Zheng 1984) from Liuzhi in Guizhou has ribbed inner whorls, but its outer whorls bear large nodes near the ventrolateral shoulders. As only a few specimens were sampled, we prefer to keep this taxon in open nomenclature.

Genus Nodopleuroceras Zheng, 1984

Type species. Nodopleuroceras guizhouense Zheng, 1984; Liuzhi and Guiyang (Guizhou); Changhsingian.

Diagnosis. Tainoceratidae with subevolute conch and subquadrate whorl profile, slightly convex venter and flattened flanks; subangular to rounded ventrolateral and umbilical margin. Sculpture with closely spaced, prorsiradiate ribs on the lateral area; ribs backward projected and extending sideways to the venter, intersect with a V-shaped sinus on the venter or discontinue at the shallow ventral groove. The ribs always bear several spiral rows of nodes on the lateral area. Suture line with a shallow ventral lobe and two broad lateral lobes.

Remarks. Nodopleuroceras was erected by Zheng (1984) based on rather poorly preserved specimens of the single species N. guizhouense from Guizhou. The ornamentation of Nodopleuroceras shows several spiral rows of nodes and sinuous ribs similar to Tainonautilus, but the ribs of Nodopleuroceras are denser and more elongated on the venter. Nodopleuroceras is similar 
to Wuchiapingian Nodonautilus of Anhui (Liang 1984) by sharing some common features, e.g. a subevolute conch and closely arranged ribs. However, Nodopleuroceras can be distinguished from Nodonautilus by its subquadrate whorl profilewith convex venter, rather shallow and narrow ventral grooves, while Nodonautilus is characterized by the thick ribs and a broad deep ventral groove. It differs from Pleuronautilus and Eulomacoceras Zhao et al., 1978 by its denser ribs on the venter, from the Wuchiapingian Paratainonautilus from Jiangxi by Qin (1986) by its nodes on the ribs, and from Clavinautilus from the Changxing Formation of West Guizhou (Zhao 1978) by the slightly arched venter without nodes.

Nodopleuroceras gujiaoense sp. nov.

Figure $8 \mathrm{~A}-\mathrm{D}$

Derivation of name. Named after the Gujiao section.

Holotype. YFMCUG 00225; illustrated in Fig. 8A.

Paratypes. YFMCUG 00226 and YFMCUG 00227.

Type locality and horizon. Gujiao section (Guizhou); bed GJ-7 in the Dalong Formation (late Changhsingian).

Material. Eleven specimens (YFMCUG 00225-YFMCUG 00236) from bed GJ-7.

Diagnosis. Nodopleuroceras with subevolute conch and subquadrate whorl profile. Ornament with closely spaced ribs which extend with shallow sinus across the flank, form a projection at the ventrolateral shoulder and a V-shaped ventral sinus. Eight spiral rows of nodes from umbilicus to mid-venter. Suture line with shallow ventral lobe and broad lateral lobes.

Description. The holotype (specimen YFMCUG 00225, Fig. 8A) has a maximum diameter of $56 \mathrm{~mm}$; it is thinly discoidal and subevolute $(\mathrm{ww} / \mathrm{dm}=0.37 ; \mathrm{uw} / \mathrm{dm}=0.39)$ with a nearly square-shaped 
whorl profile $(\mathrm{ww} / \mathrm{wh}=1.04)$. The venter is rounded, while the flanks are weakly flattened with the maximum width in the midflank area; the umbilical margin is rounded and the umbilical wall is vertical. The shell is ornamented with a combination of ribs and additional nodes, which are placed in spiral rows on the ribs. The ribs extend with a concavo-convex course, forming a shallow lateral sinus, a moderately high ventrolateral projections and a narrow, V-shaped ventral sinus. In most cases, these ribs are beginning at the umbilical margin, but occasionally, ribs are intercalated on the inner flank in some distance from the umbilicus. Eight rows of small nodes are developed on the flanks, becoming coarser towards the venter. The suture line shows a shallow ventral lobe as well as broader and deeper lateral lobes. The siphuncle has near-central position.

Remarks. When compared with Nodopleuroceras guizhouense, N. gujiaoense sp. nov. differs by its eight rows of nodes on the flanks, while the flank of $N$. guizhouense shows only three rows of nodes near the umbilical margin. Additionally, N. guizhouense shows a well-developed ventral groove, which is absent in the new species.

Occurrence. Dalong Formation (late Changhsingian), Gujiao section (Guizhou).

Genus Gujiaonautilus gen. nov.

Derivation of name. Named after the Gujiao section, the type locality.

Type species. Gujiaonautilus longliensis sp. nov.; Gujiao section (Guizhou), Changhsingian.

Included species. Gujiaonautilus longliensis sp. nov.

Diagnosis. Tainoceratidae with subevolute conch and subquadrate whorl profile. Venter convex to subtabulate with rounded to subangular ventrolateral shoulders. Wide umbilicus with rounded umbilical shoulder. Ornamentation with dense bifurcate ribs on the flanks and two rows of tubercles on the venter. Siphuncle centrally located. Suture line with shallow ventral lobe and broad lateral lobes. 
Remarks. The two rows of nodes on the venter and the dense bifurcate ribs are the most distinctive features of Gujiaonautilus. Though its conch shape and its suture line are similar to the Late Permian Pleuronautilus and Tainonautilus, it differs from these genera of the Tainoceratidae by two rows of nodes on the venter and closely arranged ribs on lateral area. Some ribs of Gujiaonautilus are intercalatory, as in Nodonautilus and Nodopleuroceras. However, Gujiaonautilus differs from Nodonautilus and Nodopleuroceras by closely arranged ribs on flanks, while the ribs of Nodonautilus and Nodopleuroceras are backward projected and extending sideways to the venter.

Gujiaonautilus longliensis sp. nov.

Figures 8E-F, 9A-C, 10A-G

Derivation of name. Named after Longli County, Guizhou, the type locality.

Holotype. YFMCUG 00248, illustrated in Fig. 10D.

Paratypes. YFMCUG 00244, YFMCUG 00245, YFMCUG 00246, YFMCUG 00250.

Type locality and horizon. Gujiao section (Guizhou); bed GJ-7 in the Dalong Formation (late Changhsingian).

Material. 49 specimens (six well-preserved specimens and 43 fragments; YFMCUG 00244YFMCUG 00291, YFMCUG 00302, YFMCUG 00303) from bed GJ7.

Diagnosis. Gujiaonautilus with a conch reaching $100 \mathrm{~mm}$ dm. Subadult stage with subquadrate, weakly depressed whorl cross section $(\mathrm{ww} / \mathrm{wh}=1.26)$ and flattened venter; adult stage with subquadrate and weakly compressed whorl profile $(\mathrm{ww} / \mathrm{wh}=0.85)$, an arched venter and rounded ventrolateral shoulders. Sculpture with closely arranged and falcoid ribs on the flanks, two rows of nodes on venter. Suture line with shallow ventral and broad, deeper lateral lobes. 
Description. The holotype (specimen YFMCUG 00248, Fig. 10D) is $72.5 \mathrm{~mm}$ in maximum diameter; it is thinly discoidal and subevolute $(\mathrm{uw} / \mathrm{dm}=0.37, \mathrm{uw} / \mathrm{dm}=0.34)$ with weakly compressed subquadrate to nearly oval whorl profile $(\mathrm{ww} / \mathrm{wh}=0.85)$. The venter is weakly convex with rounded ventrolateral shoulders; the flanks are convex with the maximum whorl width near the umbilical margin; with rounded umbilical shoulders and vertical umbilical wall. The venter bears a narrow and shallow ventral groove, bordered by two rows of slightly elongate and oblique tubercles on each side. This species displays a remarkable variation in the distances between rows of ventral nodes; the Dn/ww value range from 0.14 to 0.24 among the specimens, but is constant during ontogeny. The flanks exhibit dense and intercalary ribs. These ribs are in general weakly sinuous and sometimes two ribs develop from a single node on the umbilical shoulder; they disappear near the ventrolateral shoulder. When preserved, the shell shows conspicuous growth lines that are best visible on the venter (specimens YFMCUG 00243, YFMCUG 00250-00251); they curve backward between the ventral nodes and the end of the ribs. The suture line displays a shallow ventral lobe between the two rows of ventral nodes and broad, deeper lateral lobes.

This species shows some growth allometry. Whorls of preadult individuals display a subtabulate venter and a depressed rectangular whorl profile $(\mathrm{ww} / \mathrm{wh}=1.26$ at $\mathrm{dm}=27.7 \mathrm{~mm}$ in specimen YFMCUG 00247), while in the adult stage, the whorl profile is slightly compressed with a convex venter and rounded ventrolateral shoulders. The whorl width/diameter ratio decreases from 0.5 to ca. 0.3 during ontogeny (see Fig. 11). Changes in ontogeny can also be seen in the sculpture; in large-sized individuals, the ribs are more sinuous, slightly extended towards the venter and connected with ventral nodes.

Measurements. See online resource and Fig. 11.

Occurrence. Dalong Formation (late Changhsingian), Gujiao section (Guizhou).

Family Rhiphaeoceratidae Ruzhencev \& Shimansky, 1954

Genus Sholakoceras Ruzhencev \& Shimansky, 1954

Type species. Sholakoceras bisulcatum Ruzhencev \& Shimansky, 1954; Ural Mountains of Kazakhstan; Sakmarian. 
Diagnosis. Rhiphaeoceratidae with subevolute conch; whorl profile subquadrate, with nearly flattened ventral and flanks, rounded ventrolateral and umbilical shoulders. The flanks bear short and prorsiradiate ribs. The suture line is characterized by a very shallow ventral lobe, shallow lateral lobes and a deep funnel-shaped dorsal lobe.

Remarks. Ruzhencev \& Shimansky (1954) introduced this genus, including three species, and concluded that Sholakoceras, Rhiphaeonautilus, Rhiphaeoceras and Pararhiphaeoceras are sister genera in the same family: the Rhiphaeoceratidae. Genera belonging to this family are all widely perforate and bear plicate ribs on the flanks. A large variation among genera is also observed, especially for the whorl profile. It is characteristically subquadrate in Sholakoceras, low elliptical in Rhiphaeoceras, subtrapezoidal with a broad arched venter and narrow flanks bearing short inflated ribs in Rhiphaeonautilus, and subtrapezoidal with rounded ventrolateral shoulders and short, oblique ribs in Pararhiphaeoceras.

Liang (1981) reported the Roadian Sholakoceras transforme from Gansu (North China). Mapes et al. (2007) provided a detailed embryological discussion based on a hatched specimen of Sholakoceras pleuronautiloides from the Sosio Limestone of Sicily (Italy) and they transferred the Wordian Trematodiscus pleuronautiloides (Gemmellaro 1890) to Sholakoceras. Sholakoceras was until now, reported only from Early and Middle Permian strata; this is the first time that Sholakoceras is documented from Changhsingian beds.

\section{Sholakoceras sp.}

Figure 12A-B

Description. A single well-preserved internal mould of one and a half whorls with complete protoconch is available. The conch is subevolute $(\mathrm{dm} / \mathrm{uw}=0.40$ at $33 \mathrm{~mm}$ diameter $)$, with a subquadrate whorl profile $(\mathrm{ww} / \mathrm{wh}=1.10)$. The subtabulate venter bears a double row of small elongated nodes in centre. The $\mathrm{Dn} / \mathrm{ww}$ ratio is 0.24 at $\mathrm{wh}=12.1 \mathrm{~mm}$. The flanks converge slightly towards the subangular ventrolateral shoulders with the maximum whorl width at the umbilical shoulders. The flanks are ornamented with prorsiradiate ribs. The umbilical perforation is rather large 
(8.1 $\mathrm{mm}$ in diameter) with a conical protoconch. The adapical ornament is conspicuous with densely arranged transverse plications. The suture line is almost straight with an inconspicuous ventral lobe and broad shallow lateral lobes.

Remarks. This specimen is perforate and bears plicate ribs on the flanks, with a subquadrate whorl profile, which are all features of Sholakoceras. Nevertheless, elongated ventral nodes were not reported so far for any species of this genus. As only one rather small internal mould is available, we prefer to keep this taxon in open nomenclature.

Family Liroceratidae Miller \& Youngquist, 1949

Genus Liroceras Teichert, 1940

Type species. Coloceras liratum Girty, 1911; Oklahoma (Unites States).

Diagnosis. Liroceratidae characterized by involute, globular and smooth conch with depressed whorl profile. Umbilicus is small or occluded. The suture line is almost straight.

Remarks. A detailed discussion of this genus is available in Barskov et al. (2014). Liroceras differs as follows from other genera of the Liroceratidae: Paranautilus has a depressed whorl profile (which is rather depressed whorl in Liroceras), Peripetoceras shows a more quadrate whorl profile with subangular umbilical shoulders and Coelogasteroceras differs from Liroceras by the presence of a ventral groove. Permonautilus exhibits coarse growth lines and often spiral lines, as well as long umbilical projections of the shell in the adult stage.

Liroceras lichuanense Wu \& Kuang, 1992

Figure 13A, B

v. 1992 Liroceras lichuanense Wu \& Kuang, p. 291, pl. 1, figs. 2, 3, 5.

Lectotype. Specimen LJ242; illustrated by Wu \& Kuang (1992, pl. 1, fig. 3.)

Diagnosis. Liroceras with subglobular and smooth conch and slightly depressed horseshoe-shaped 
whorl profile; arched venter and flanks without ventrolateral shoulders. Umbilicus occluded. Suture line almost straight.

Material. Two large phragmocones (YFMCUG 00292-YFMCUG 00293) from the GJ-7 are available.

Description. The larger specimen YFMCUG 00292 is slightly squashed and measures $108 \mathrm{~mm}$ in maximum diameter. It has a weakly depressed horseshoe-shaped whorl profile that is wider than high $(\mathrm{ww} / \mathrm{wh}=1.37)$. The venter is broadly arched without ventrolateral shoulders and the umbilicus is occluded. The shell is smooth with obvious growth lines, which bend in a broad and shallow U-shape sinus on the venter. The suture line is almost straight without obvious lobes and saddles.

Remarks. The specimens of Liroceras lichuanense from the Gujiao section are much larger than those from Lichuan (Wu \& Kuang, 1992). L. lichuanense is characterized by its occluded umbilicus and a depressed crescent whorl profile, which makes it different from many species that possess an open umbilicus. This species differs from L. chenxianense (Liang 1984) by its depressed whorl profile, while the whorl profile of $L$. chenxianense is oval with the maximum whorl width at middle of the flanks.

Occurrence. Reefs of Lichuan (Hubei, South China), Dalong Formation (late Changhsingian) at Gujiao section (Guizhou).

Liroceras orientale Zhao, 1954

Figures $13 \mathrm{C}, 14 \mathrm{~A}-\mathrm{C}$

1954 Liroceras orientale Zhao, p.13, pl. 5, figs. 1, 2.

Holotype. Specimen 7133 illustrated by Zhao (1954, pl. 5, fig. 1, 2).

Diagnosis. Liroceras with subinvolute, globular, smooth conch with depressed kidney-shaped whorl whorl profile; arched venter and flanks without ventrolateral shoulders; umbilical shoulders narrowly 
rounded. Umbilicus deep and broad with a vertical umbilical wall. Suture line almost straight.

Material. Two large internal moulds (YFMCUG 00294 and YFMCUG 00298) and three well-preserved small individuals (YFMCUG 00295-YFMCUG 00297) from the Gujiao section GJ-7 are available.

Description. Specimen YFMCUG 00294 is the largest one available with $84 \mathrm{~mm}$ in maximum diameter. It displays a globular and subinvolute conch $(\mathrm{uw} / \mathrm{dm}=0.93 ; \mathrm{uw} / \mathrm{dm}=0.19$ at maximum diameter) associated with a moderately depressed kidney-shaped whorl profile (ww/wh $=1.81$ at maximum diameter). The venter is broadly rounded without ventrolateral shoulders. The flanks are also broadly arched. The umbilical shoulder is narrowly rounded in juvenile whorls and becomes more broadly rounded during ontogeny. One small phragmocone (specimen YFMCUG 00296) with preserved shell on the umbilical wall of the outer whorl, shows a small and deep umbilicus with a vertical umbilical wall. The suture line is almost straight with a broad and inconspicuous ventral lobe.

Remarks. Liroceras orientale is similar to the Kungurian L. sinense (Zhao 1954) with its depressed crescent-shaped whorl profile, but L. orientale has a higher expansion rate with a deeper and larger umbilicus. The umbilical shoulder of L. hunanense (Zhao 1954) is more rounded. L. orientale differs from L. lichuanense by the deeper and larger umbilicus.

Occurrence. Kungurian at Tanjiashan (Hunan, South China); Dalong Formation (late Changhsingian) at Gujiao section (Guizhou).

Family Trigonoceratidae Hyatt, 1884

Genus Aulagonoceras Zheng, 1984

Type species. Aulagonoceras plicatum Zheng, 1984; Zhongying section (Guizhou); Dalong Formation (Changhsingian).

Diagnosis. Trigonoceratidae with almost subevolute conch and compressed subtrapezoidal or 
reniform whorl profile. Concave venter with one or more ventral grooves. Flanks variously convex. Ventrolateral and umbilical shoulders subangular to angular with sharp margins. Sculpture with four or more rows of ridges located on the venter, ventrolateral shoulders and flanks. Suture line with narrow ventral lobes in ventral grooves, rather broad lateral lobes. Growth lines well visible and forming a in the broad and deep U-shape sinus on the venter.

Remarks. Aulagonoceras is only known from Changhsingian sediments of South China and includes three species: A. plicatum, A. spirale and A. bispirale (Zheng 1984). This genus is characterized by a reniform whorl profile, coarse growth lines and four or more ridges located on the venter, ventrolateral shoulders and flanks. Aphelaeceras, from the same family and only found in Changhsingian strata of West Guizhou (Zheng 1984), is close to Aulagonoceras. However, it has a much more compressed conch with fewer ridges; it also exhibits a deeper ventral groove. Wu \& Kuang (1992) described Aulagonoceras jiantianbaense from a Changhsingian reef at Lichuan. However, according to the definition of Aulagonoceras, A. jiantianbaense should be excluded from this genus, because it has a compressed and oval whorl profile with rounded ventrolateral shoulders, ribs and a ventral strigation, all these features differing from Aulagonoceras.

\section{Aulagonoceras plicatum Zheng, 1984}

Figure $15 \mathrm{~A}-\mathrm{C}$

v. 1984 Aulagonoceras plicatum Zheng, p. 249, pl. 4, figs. 7-9, 16-22, 28, text-figs. 12d, 13 a.

Holotype. Specimen NIGPAS 34393 illustrated by Zheng (1984, pl. 4, figs. 4-6).

Type locality and horizon. Zhongying section in Qinglong, Guizhou; Dalong Formation (Changhsingian).

Diagnosis. Aulagonoceras with subevolute conch and compressed subtrapezoidal whorl profile. Concave venter incised with three grooves, of which the central one is deepest; flanks convex. Ventrolateral and umbilical shoulders subangular to angular. Sculpture with four rows of ridges located on venter. Suture line with narrow ventral lobes in ventral grooves, rather broad lateral lobes. 
Material. This species is rare in the sampled fauna; only two specimens (YFMCUG 00299 and YFMCUG 00300) were excavated.

Description. Specimen YFMCUG 00299 shows a subevolute conch (uw/dm $=0.32$ at $\mathrm{wh}=9.5 \mathrm{~mm})$ and a weakly depressed, subtrapezoidal whorl profile. The ww/wh ratio shows a large intraspecific variation, ranging from 0.32 to 0.74 . The venter is concave with three grooves, of which the central one is the deepest; the grooves are separated by four ridges on the venter and the subangular ventrolateral shoulders. The flanks are slightly convex and converge towards the venter with the maximum whorl width at the umbilical shoulders. The flank is slightly concave between the ventrolateral margin and flank ridge. Umbilical shoulder is broadly subangular and bears carinas. The growth lines bent forward on the flanks, turn backward rapidly from the flank ridges and bend forward to form projections on the venter between two ventrolateral keels. The suture line shows a narrow shallow ventral lobe, saddles on the ventrolateral keel, broad lateral lobes.

Remarks. The number of ridges on the conch is the essential difference among the species of Aulagonoceras. A. plicatum (Zheng, 1984) is characterized by four ridges on the venter and the ventrolateral shoulders and has marked growth lines, while A. spirale (Zheng, 1984) has eight ridges on the venter and the flank without obvious growth lines. A. bispirale (Zheng, 1984) bears two ridges on the flank and has a total of ten ridges on conch.

Occurrence. Dalong Formation, Zhongying section (Zheng 1984) and Gujiao section (Guizhou); late Changhsingian.

Family Grypoceratidae Hyatt, 1900

Genus Pseudotitanoceras Shimansky, 1965

Type species. Pseudotitanoceras armeniacum Shimansky, 1965; Azerbaijan; 'Dzhulfian Stage' (Wuchiapingian).

Diagnosis. Grypoceratidae with smooth, moderately subevolute conch and subtrapezoidal whorl 
profile. Venter flattened to concave; flanks slightly convex and converging towards the rounded ventrolateral shoulders with the maximum width at the rounded umbilical margin. Small and deep umbilicus with almost vertical wall. Sculpture with double row of elongated and low nodes on ventrolateral shoulders.

Remarks. Shimansky (1965) erected Pseudotitanoceras based on Nautilus armeniacus (Abich 1878) as its type species. Following the work of Shimansky (1965), Teichert and Kummel (1973) reported Pseudotitanoceras armeniacum from the Julfa Formation of Iran. Pseudotitanoceras was also documented in the Akhura Formation of Azerbaijan and Armenia (Kotlyar et al. 1983) and the Hambast Formation of Central Iran (Taraz 1971) and the Dalong Formation of Guizhou (Zheng 1984).

Pseudotitanoceras sp.

Figure 15D

Description. The single small sampled specimen (YFMCUG 00301) is subinvolute ( $\mathrm{uw} / \mathrm{dm}=0.27$ at $28 \mathrm{~mm}$ diameter) with a nearly quadrate, subtrapezoidal whorl profile $(\mathrm{ww} / \mathrm{wh}=0.96)$. The ventral area is smooth and almost flat. The ventrolateral shoulder is subangular to angular and bearing a row of elongate nodes. The flanks are flattened and convergent to the ventrolateral shoulders with the maximum width at the umbilical margins. The umbilical wall is flattened. The suture line is not visible on the specimen.

Remarks. The tabulate venter and the elongate ventrolateral nodes are typical features of Pseudotitanoceras. This specimen differs from P. armeniacum by distinct ventrolateral shoulders. It is much similar to Pseudotitanoceras sp. from the Changhsingian of Liuzhi and Qinglong (Zheng 1984), with its subtrapezoidal whorl profile and small elongate nodes on the angular ventrolateral shoulders. With only one small specimen, we prefer to leave it in open nomenclature.

\section{CONCLUSIONS}

A new nautiloid assemblage was found in the Dalong Formation at Gujiao (Guizhou). It contains abundant specimens of nine species and five taxa in open nomenclature in nine identified genera, 
including the new genus Gujiaonautilus and the three new species Neotainoceras zhaoi, Nodopleuroceras gujiaoense and Gujiaonautilus longliensis. The three new species belong to the Tainoceratidae, which is the most diverse and dominant family among all Changhsingian nautiloid assemblages in South China. The composition of these assemblages from South China was probably influenced by the water depth: assemblages from deep water facies are dominated by Tainoceratidae, while nautiloids from shallow settings are mainly dominated by Liroceratidae. Worldwide, sites yielding Changhsingian nautiloids are located in low and middle palaeolatitude areas of the Tethys. Based on previously published data and our observations, three of the nine genera from Gujiao, Tainoceras, Pleuronautilus and Liroceras are cosmopolitan; Gujiaonautilus, Neotainoceras and Aulagonoceras are only known from South China.

\section{ACKNOWLEDGMENTS}

We are indebted to We greatly acknowledge an anonymous reviewer and Jerzy Dzik (Warsaw) for their valuable comments on an earlier version of the manuscript and Sally Thomas (London) as well as Michael Hautmann (Zurich) for their suggestions.. We acknowledge Yi Wang for his help in the field. Jia Yan, Zhipu Qiu, Mingtao Li, Fengyu Wang and Enhao Jia is thanked for her support with photographic work and interior work. This work benefited from the help of Cheng Ji and Qiulai Wang (Nanjing) to access comparable specimens. This study is supported by the National Natural Science Foundation of China (grant no. 41622207, 41672016). Dieter Korn acknowledges the support by the German Research Foundation (DFG projects Ko1829/12-1, Ko1829/17-1) and the National Natural Science Foundation of China (grant no. 41630101). Arnaud Brayard acknowledges the support by the ANR project AFTER (ANR-13-JS06-0001-01) and the French "Investissements d'Avenir" program, project ISITE-BFC (ANR-15-IDEX-03). The project was supported by the Fundamental Research Founds for National University, China University of Geosciences (Wuhan).

\section{DATA ARCHIVING STATEMENT}

This published work and the nomenclatural acts it contains, have been registered in ZooBank: http://zoobank.org/References/E74B2E81-6DCF-4199-98C8-B51EF6A5173F

\section{REFERENCES}


ABICH, H. 1878. Geologische Forschungen in den Kaukasischen Ländern. Theil 1. Eine Bergkalkfauna aus der Araxesenge bei Djoulfa in Armenien. Alfred Hölder, Wien, 126 pp.

AGASSIZ, L. 1847. Classification of Mollusca. An Introduction to the Study of Natural History: In a Series of Lectures Delivered in the Hall of the College of Physicians and Surgeons, New York. Greeley \& McElrath, 20 pp.

BARSKOV, I. S., LEONOVA, T. B. and SHILOVSKY, O. P. 2014. Middle Permian cephalopods of the Volga-Ural Region. Paleontological Journal, 48, 1331-1414.

BENGTSON, P. 1988. Open nomenclature. Palaeontology, 31, 223-227.

BRAYARD, A., ESCARGUEL, G., BUCHER, H., MONNET, C., BRUHWILER, T., GOUDEMAND, N., GALFETTI, T. and GUEX, J. 2009. Good genes and good luck: Ammonoid diversity and the end-Permian mass extinction. Science, 325, 1118-1121.

CHIRAT, R., VASLET, D., LE NINDRE, Y. 2006. Nautiloids of the Permian-Triassic Khuff Formation, central Saudi Arabia. GeoArabia, 11, 81-92.

CUVIER, J. L. N. F. 1797. Tableau élémentaire de l'histoire naturelle des animaux. Baudouin, Paris, 770 pp.

DAI, X., SONG, H., BRAYARD, A. and WARE, D. 2019. A new Griesbachian-Dienerian (Induan, Early Triassic) ammonoid fauna from Gujiao, South China. Journal of Paleontology, 48-71.

DAI, X., SONG, H., WIGNALL, P. B., JIA, E., BAI, R., WANG, F., CHEN, J. and TIAN, L. 2018. Rapid biotic rebound during the late Griesbachian indicates heterogeneous recovery patterns after the Permian-Triassic mass extinction. Bulletin, 130, 2015-2030.

DZIK, J. 1984. Phylogeny of the Nautiloidea. Palaeontologia Polonica, 45, 1-324.

ERWIN, D. H. 1994. The Permo-Triassic extinction. Nature, 367, 231-236.

FENG, Q. and GU, S. 2002. Uppermost Changxingian (Permian) radiolarian fauna from southern Guizhou, southwestern China. Journal of Paleontology, 76, 797-809.

FENG, Z., BAO, Z. and LIU, S. 1997. Lithofacies Palaeogeography of Early and Middle Triassic of South China. Petroleum Industry Press, Beijing, 222 pp.

FOORD, A. H. 1891. Catalogue of the Fossil Cephalopoda in the British Museum (Natural History), Part 2, containing the remainder of the suborder Nautiloidea, consisting of the families Lituitidae, Trochoceratidae, and Nautilidae, with a supplement. London, $407 \mathrm{pp}$.

GEMMELlARO, G. G. 1890. La Fauna dei calcari con Fusulina della valle del fiume Sosio nella Provincia di Palermo 2. Cephalopoda, Nautiloidea, Gastropoda. Giornale di Science Naturali ad Economiche, 20, 97-182.

GIRTY, G. H. 1911. On some new genera and species of Pennsylvanian fossils from the Wewoka Formation of Oklahoma. Annals of the New York Academy of Sciences, 21, 119-156.

GROVES, J. R., ALTINER, D. and RETTORI, R. 2005. Extinction, survival, and recovery of lagenide foraminifers in the Permian-Triassic boundary interval, Central Taurides, Turkey. Journal of Paleontology, 79 suppl., 1-38.

HE, W. H., SHI, G., TWITCHETT, R., ZHANG, Y., ZHANG, K. X., SONG, H. J., YUE, M. L., WU, S. B., WU, H. T. and YANG, T. L. 2015. Late Permian marine ecosystem collapse began in deeper waters: evidence from brachiopod diversity and body size changes. Geobiology, 13, 123-138.

HYATT, A. 1883-1884. Genera of fossil cephalopods. Proceedings of the Boston Society of Natural History, 22, 253272 .

--- 1900. Cephalopoda. Zittel, KA: Text book of Palaeontology. Macmillan, Beijing, 502 pp.

ISHIBASHI, T., NAKORNSRI, N. and NAGAI, K. 1994. Permian-Triassic boundary and fauna at Doi Pha Phlung, northern Thailand. Memoirs of the Faculty of Science, Kyushu University, Series D, Earth and Planetary Science, 28, 23-40.

JIA, E. and SONG, H. 2018. End-Permian mass extinction of calcareous algae and microproblematica from Liangfengya, South China. Geobios, 51, 401-418. 
JIANG, H., WIGNAll, P. B., CHEN, Z.-Q., XIE, S., LAI, X., SONG, H. and WANG, L. 2017. Comment on "Quantitative biochronology of the Permian-Triassic boundary in South China based on conodont unitary associations" by Brosse et al.(2016). Earth-Science Reviews, 164, 257-258.

JURKOVŠEK, B., KOLAR-JURKOVŠEK, T. and JAECKS, G. S. 2002. Mikrofavna karnijskih plasti mežiškega prostora. Geologija, 45, 413-418.

KAYSER, E., 1883. Obercarbonische Fauna von Lo-ping. in: Richthofen, F.v. (Ed.), China, pp. 160-208.

KORN, D. 2010. A key for the description of Palaeozoic ammonoids. Fossil Record, 13, 5-12.

KOTLYAR, G.V., ZAKHAROV, Y.D., KOCZYRKEVICZ, B.V., KROPATCHEVA, G.S., ROSTOVCEV, L.O., CHEDIJA, I.O., VUKS, G.P., GUSEVA, E.A., 1983. Posdnepermskiy etap evolyutsii organicheskogo mira. Dzhulficheskiy i dorashamskiy yarusy SSSR. Leningrad: NAUKA, 1-200.

KOTLYAR, G. V., ZAKHAROV, Y. D., KROPATCHEVA, G. S., PRONINA, G. P., CHEDIJA, I. O. and BURAGO, V. I. 1989. Posdnepermskiy etap evolyutsii organicheskogo mira. Midiskiy yarus SSSR. Leningrad: NAUKA, 1-185.

KULIKOV, M. V. and TKACHUK, G. A. 1979. Find of Claraia (Bivalvia) in the Upper Permian of the northern Caucasus. Doklady Akademii Nauk SSSR, 245, 905-908.

KUMMEL, B. 1953. American Triassic coiled nautiloids. United States Geological Survey Professional Paper, 250, 1104.

KUMMEL, B. and TEICHERT, C. 1970. Stratigraphy and paleontology of the Permian-Triassic boundary beds, Salt Range and Trans-Indus Ranges, West Pakistan. 1-110. In KUMMEL, B. and TEICHERT, C. (eds). Stratigraphic Boundary Problems: Permian and Triassic of West Pakistan. The University Press of Kansas, pp. Custom 7.

LAI, X., JIANG, H. and WIGNALL, P. B. 2018. A review of the Late Permian-Early Triassic conodont record and its significance for the end-Permian mass extinction. Revue de Micropaléontologie, 61, 155-164.

LAWS, R. A. 1982. Late Triassic depositional environments and molluscan associations from west-central Nevada. Palaeogeography, Palaeoclimatology, Palaeoecology, 37, 131-148.

LEHRMANN, D. J., WEI, J. and ENOS, P. 1998. Controls on facies architecture of a large Triassic carbonate platform: the Great Bank of Guizhou, Nanpanjiang Basin, South China. Journal of Sedimentary Research, 68, 311-326.

LIANG, X. 1981. Early Permian Cephalopods from Northwestern Gansu and Western Nei Monggol. Acta Palaeontologica Sinica, 20, 485-500.

--- 1984. Some Nautiloids of Late Permian. Acta Palaeontologica Sinica, 23, 699-704+794-795.

MAPES, R. H., NIKO, S., FRYDA, J. and NÜTZEL, A. 2007. A newly hatched coiled nautiloid from the Permian of Italy. Journal of Paleontology, 81, 1118-1121.

MATTHEWS, R. A. 1973. The life-cycle of Bucephalus haimeanus Lacaze-Duthiers, 1854 from Cardium edule L. Parasitology, 67, 341-350.

MCCHESNEY, J. H. 1860. Descriptions of new species of fossils from the Palaeozoic rocks of the western states. Transactions of Chicago Academy of Science, 1, 1-76.

McGOWAN, A. J., SMITH, A. B. and TAYLOR, P. D. 2009. Faunal diversity, heterogeneity and body size in the Early Triassic: testing post-extinction paradigms in the Virgin Limestone of Utah, USA. Australian Journal of Earth Sciences, 56, 859-872.

MILLER, A.K., YOUNGQUIST, W.L., 1949. American Permian nautiloids. Geological Society of America Memoirs, 41, $1-28$.

MOJSISOVICS, E. V. M. 1882. Die Cephalopoden der mediterranen Triasprovinz. Abhandlungen der Kaiserlich-Königlichen Geologischen Reichsanstalt, 10, 1-332.

MOJSISOVICS, E. V. M. 1902. Das Gebirge um Hallstatt. Die Cephalopoden der Hallstätter Kalke. 1. Band. Abhandlungen der kaiserlichen und königlichen geologischen Reichsanstalt, 6, 175-356.

ORCHARD, M. J. 2007. Conodont diversity and evolution through the latest Permian and Early Triassic upheavals. 
Palaeogeography, Palaeoclimatology, Palaeoecology, 252, 93-117.

POSENATO, R. 2010. Marine biotic events in the Lopingian succession and latest Permian extinction in the Southern Alps (Italy). Geological Journal, 45, 195-215.

POSENATO, R. and PRINOTH, H. 2004. Orizzonti a nautiloidi e a brachiopodi della Formazione a Bellerophon (Permiano Superiore) in Val Gardena (Dolomiti). Geo.Alp, 1, 71-85.

PRINOTH, H., POSENATO, R., 2007. Late Permian Nautiloids from the Bellerophon Formation of the Dolomites (Italy). Palaeontographica Abteilung A, 282, 135-165.

QIN, Z. 1986. New Material of Early Late Permian Cephalopods in Fengcheng-Gaoan Area, Jiangxi. Acta Palaeontologica Sinica, 25, 272-283+359-361.

REED, F. R. C. 1931. New fossils from the Productus Limestones of the Salt Range, with notes on other species. Memoirs of the Geological Survey of India, Palaeontologia Indica, 17, 1-56.

--- 1944. Brachiopoda and Mollusca from the Productus limestones of the Salt Range. Palaeontologia Indica, new series, 23, 1-768.

RUZHENCEV, V. E. and SHIMANSKY, V. N. 1954. Nizhnepermskie svernutye i sognutie nautiloidei yuzhnogo Urala. Trudy Paleontologicheskogo Instituta Akademiya Nauk SSSR, 50, 1-152.

SCOTESE, C. R. 2001. Atlas of earth history, Volume 1, Paleogeography. PALEOMAP Project, Arlington, 52 pp.

SCOTESE, C. R. 2014. Atlas of Middle \& Late Permian and Triassic Paleogeographic Maps, maps 43-48 from Volume 3 of the PALEOMAP Atlas for ArcGIS (Jurassic and Triassic) and maps 49-52 from Volume 4 of the PALEOMAP PaleoAtlas for ArcGIS (Late Paleozoic). PALEOMAP Project, Evanston, IL.

SHEN, S. and SHI, G. R. 2002. Paleobiogeographical extinction patterns of Permian brachiopods in the Asian western Pacific region. Paleobiology, 28, 449-463.

SHIMANSKY, V. N. 1965. Podotryad Nautiloidea. Trudy Paleontologicheskogo Instituta Akademiya Nauk SSSR, 108, $157-165$.

SHIMANSKY, V. N. 1992. Permskie Nautilida Pamira (Permian nautilids of the Pamirs). Byulleten Moskovskogo Obshchestva Ispytatelei Prirody, Otdel Geologicheskiy, 67, 77-84.

SOBOLEV, E. 1989. Triassic Nautilida of North-East Asia. Transactions of the Institute of Geology and Geophysics, Siberian Branch. Ac. Sci. USSR, 727.

SOBOLEV, E. S. 1994. Stratigraphic range of Triassic Boreal Nautiloidea. Mémoires de Géologie de Lausanne, 22, 127138.

SONG, H., TONG, J. and CHEN, Z. Q. 2011. Evolutionary dynamics of the Permian-Triassic foraminifer size: Evidence for Lilliput effect in the end-Permian mass extinction and its aftermath. Palaeogeography, Palaeoclimatology, Palaeoecology, 308, 98-110.

SONG, H., WIGNALL, P. B., TONG, J. and YIN, H. 2013. Two pulses of extinction during the Permian-Triassic crisis. Nature Geoscience, 6, 52-56.

STANLEY, S. M. 2016. Estimates of the magnitudes of major marine mass extinctions in earth history. Proceedings of the National Academy of Sciences, 113, E6325-E6334.

TARAZ, H., 1971. Uppermost Permian and Permian-Triassic Transition beds in Central Iran. Bulletin of the American Association of Petroleum Geologists, 55, 1280-1294.

TEICHERT, C. and KUMMEL, B. 1973. Nautiloid cephalopods from the Julfa Beds, Upper Permian, Northwest Iran. Bulletin of the Museum of Comparative Zoology, 144, 409-433.

VÖRÖS, A. 2001. Middle Triassic (Anisian) nautilid cephalopods from Aszófő (Balaton Highland, Hungary). Fragmenta Palaeontologica Hungarica, 19, 1-14.

VILLIER, L. and KORN, D. 2004. Morphological disparity of ammonoids and the mark of Permian mass extinctions. Science, 306, 264-266. 
WAAGEN, W., 1879. Salt Range fossils, 1. Productus Limestone fossils. Palaeontologia Indica, 1, 1-85.

WANG, M. Q. 1990. Late Permian and early Early Triassic ammonoid fauna of Fenghai, Yong'an, Fujian and their stratigraphic significance. Acta Palaeontologica Sinica, 29, 755-773.

WU, S. and KUANG, W. 1992. Study of Nautiloids in the upper Permian Changxingian Reefs from Lichuan, West Hubei. Acta Palaeontologica Sinica, 17, 289-294+363-364.

YANG, Z., YIN, H., WU, S., YANG, F., DING, M. and XU, G. 1987. Permian-Triassic boundary stratigraphy and fauna of South China. Geological Publishing House, Beijing, 379 pp.

YAO, Z., XU, J., ZHENG, Z., ZHAO, X. and MO, Z. 1980. On the biostratigraphy of the Permian and the boundary between the Permian and Triassic in western Guizhou-eastern Yunnan. Late Permian coal bearing strata and biota from western Guizhou and eastern Yunnan. Science Press, Beijing, 1-69.

ZAKHAROV, Yu. D. 1978. Rannetriasovye ammonoidei vostoka SSSR. Nauka, 224 pp.

ZHAO, J. 1954. Permian Cephalopods from Tanjiashan, Hunan. Acta Palaeontologica Sinica, 2, 1-23+53-57+109-115.

ZHAO, J., LIANG, X. and LIANG, Z. 1978. Late Permian cephalopods of south China. Palaeontologia Sinica, New Series $B, 12,1-194$.

ZHENG, Z. 1984. Late Permian Nautiloids from Western Guizhou. Acta Palaeontologica Sinica, 23, 239-253+281$284+286$.

\section{FIGURE CAPTIONS}

FIG. 1. A, Changhsingian palaeogeographic reconstruction, modified from Scotese (2001). The star indicates the Gujiao locality. B. Changhsingian palaeogeographic map of South China showing location of the studied site, modified from Feng et al. (1997) and Lehrmann et al. (1998). NPJB, Nanpanjiang Basin. C. Field view of the Gujiao section. D. Simplified lithology of the Changxing and Dalong formations at the Gujiao section. 

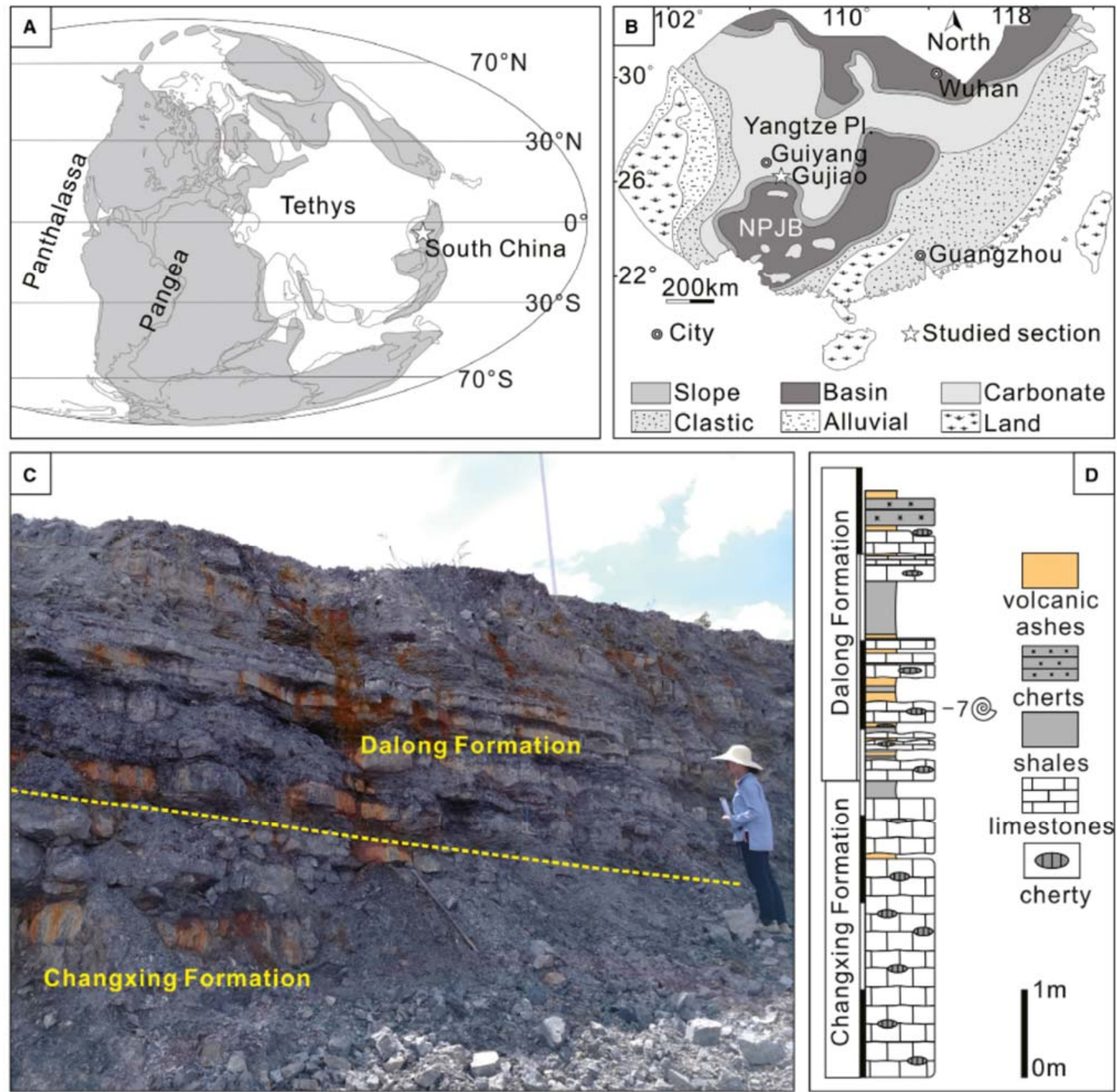
FIG. 2. Distribution of nautiloids in the Dalong and Daye formations at Gujiao, and co-occurring Changhsingian ammonoid Pseudotirolites sp. Occurrences of nautiloids in the Triassic Daye Formation are from Dai et al. (2018). 


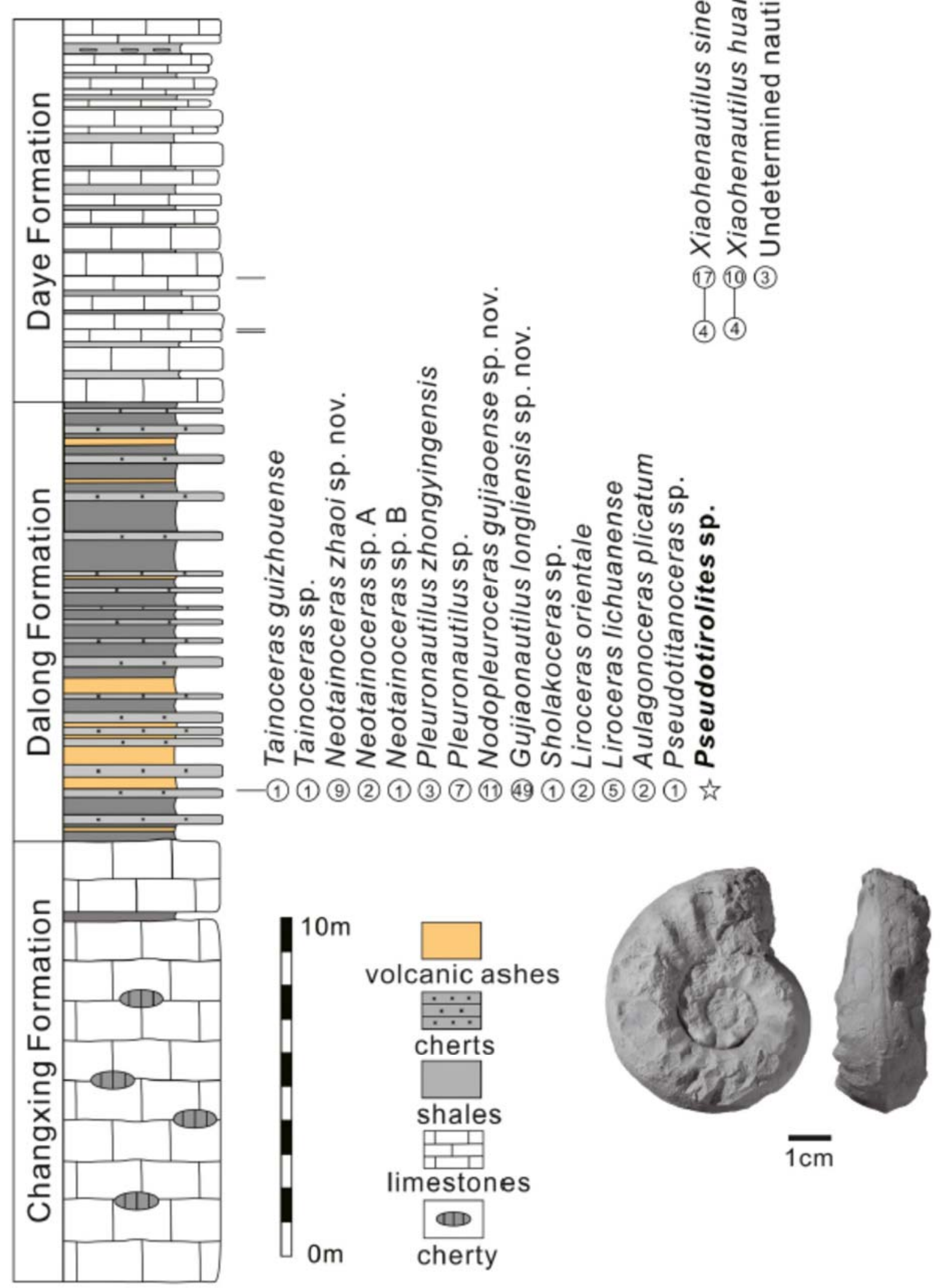


FIG. 3. Palaeo-positions of known Changhsingian nautiloid occurrences worldwide;

palaeogeographic map modified from Scotese (2014). PK, Pakistan; SA, Saudi Arabia; TH, Thailand; TI, Transcaucasia-Iran basin (including Armenia, Azerbaijan, Iran); IT, Italy; SC, South China; RU, Psebay (Russia); TJ, Tajikistan.

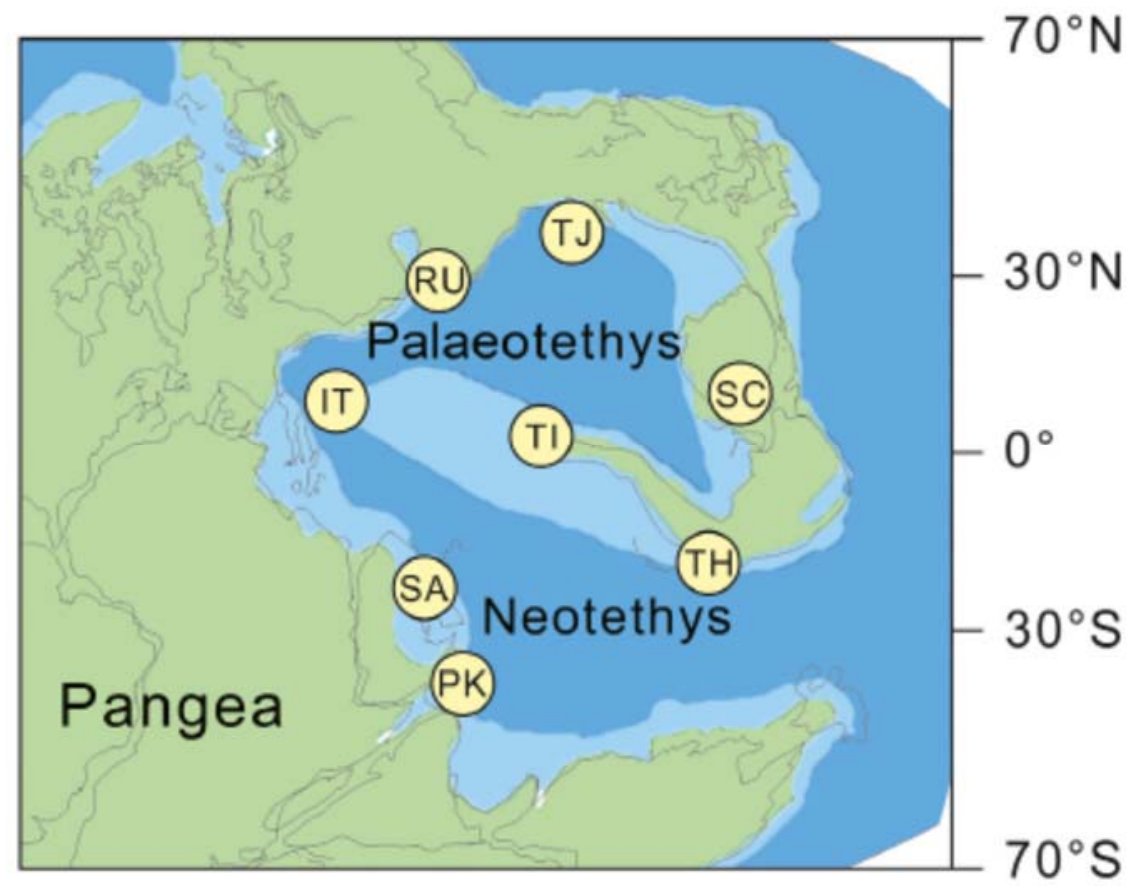


FIG. 4. A-B, Tainoceras guizhouense (Zheng, 1984) from Gujiao (Guizhou). A, YFMCUG 00201. B, suture line of YFMCUG 00201, at $w \mathrm{~h}=35.5 \mathrm{~mm}$. C, Tainoceras sp., YFMCUG 00202. D-G, Neotainoceras zhaoi sp. nov. from Gujiao (Guizhou). F, YFMCUG 00203 (holotype). D, YFMCUG 00204 (paratype). E, YFMCUG 00205(paratype). G, suture line of YFMCUG 00204, at wh = 12.5 $\mathrm{mm}$. Scale bars $=10 \mathrm{~mm}$. 

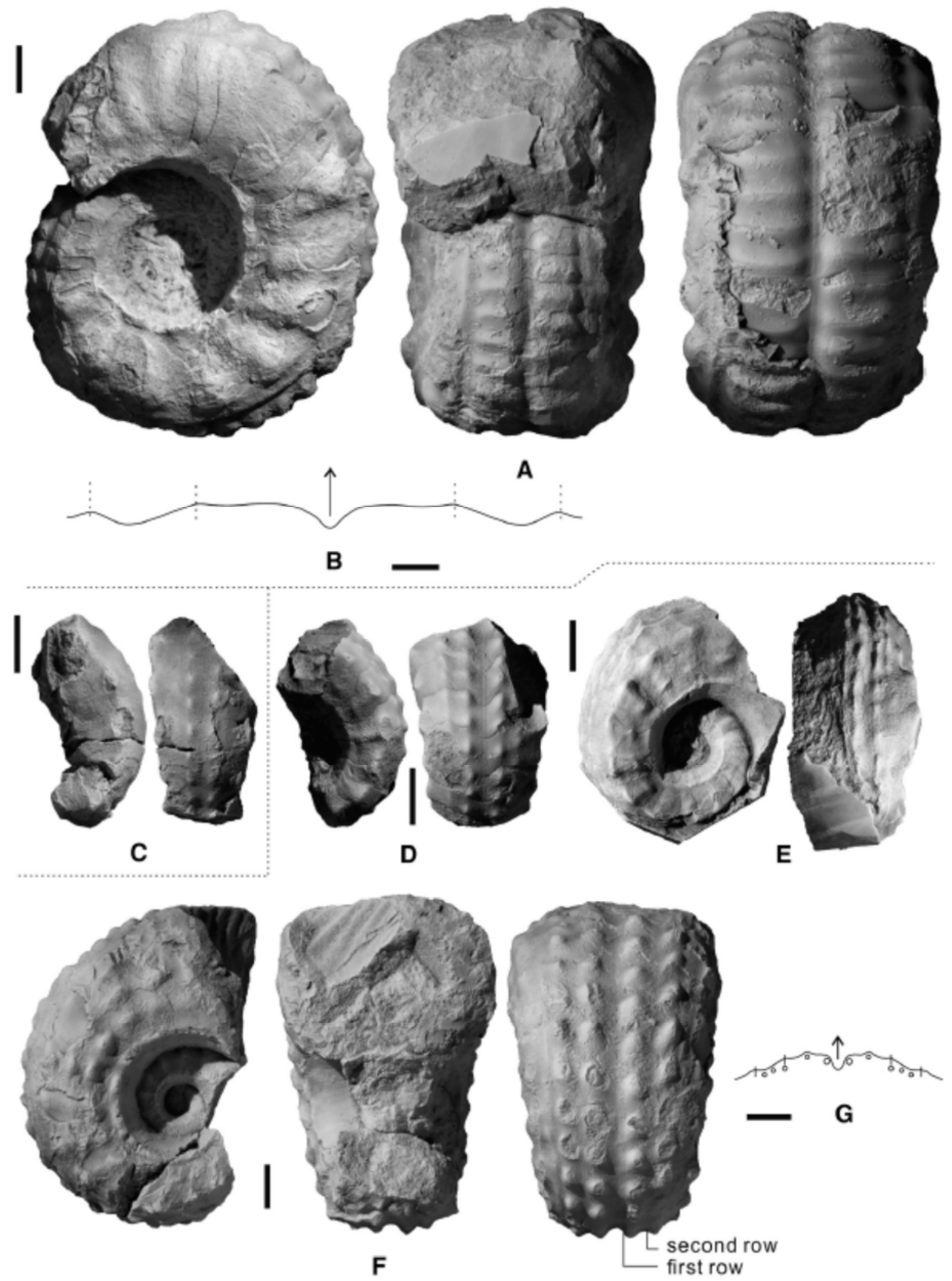
FIG. 5. A-C, Neotainoceras zhaoi sp. nov. from Gujiao (Guizhou). A, YFMCUG 00206 (paratype).

B, YFMCUG 00207 (paratype). C, YFMCUG 00208 (paratype). D-E, Neotainoceras sp. A. D, YFMCUG 00212. E, YFMCUG 00213. Scale bars $=10 \mathrm{~mm}$.
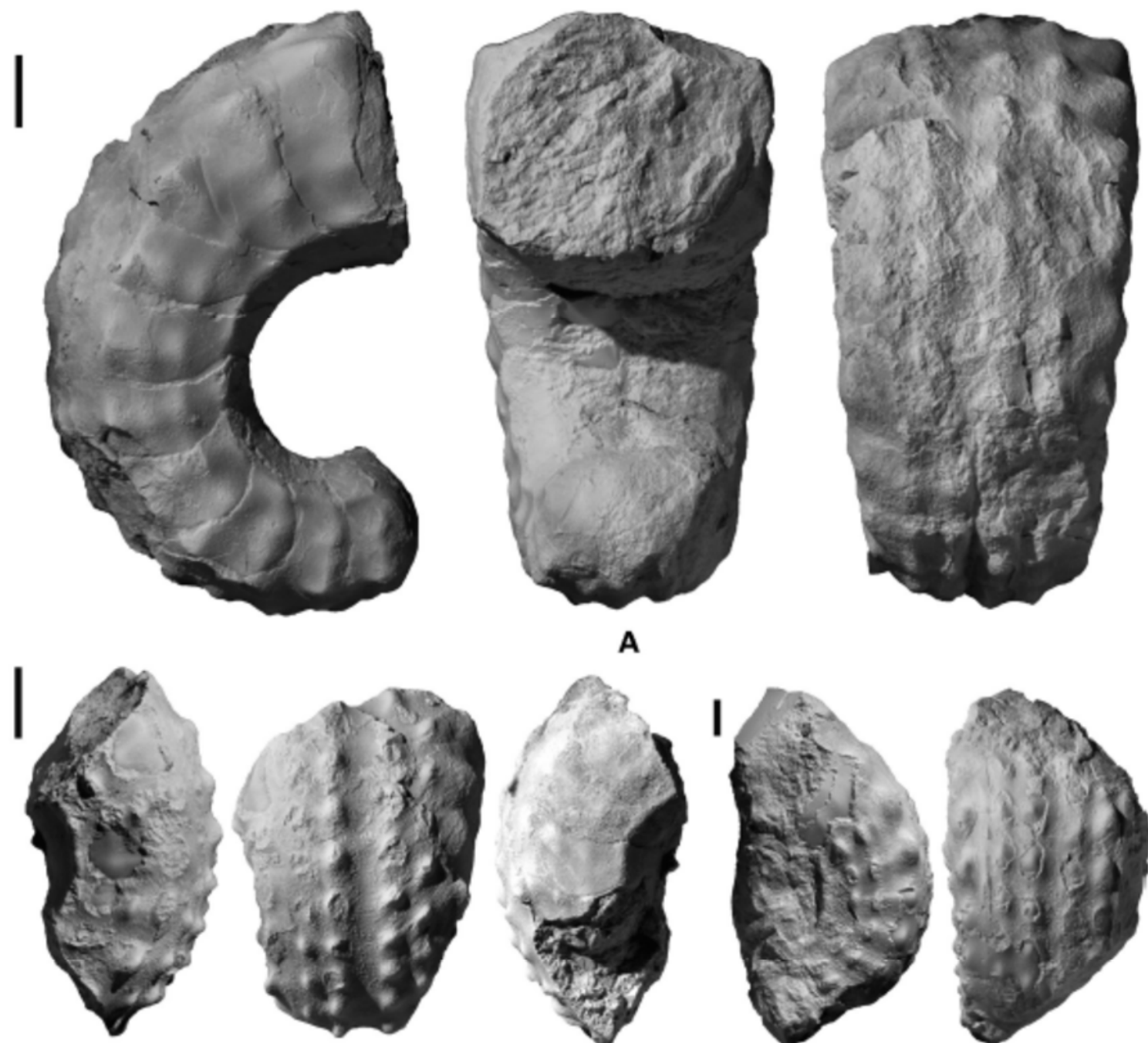

B
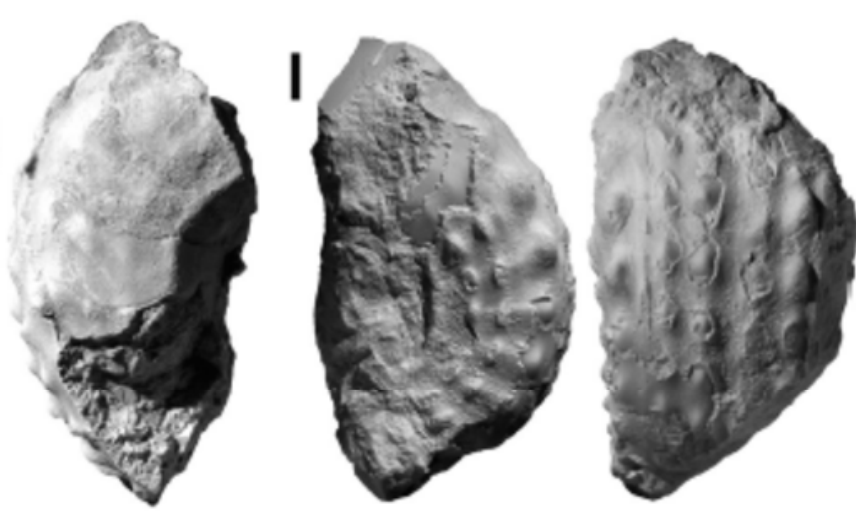

C

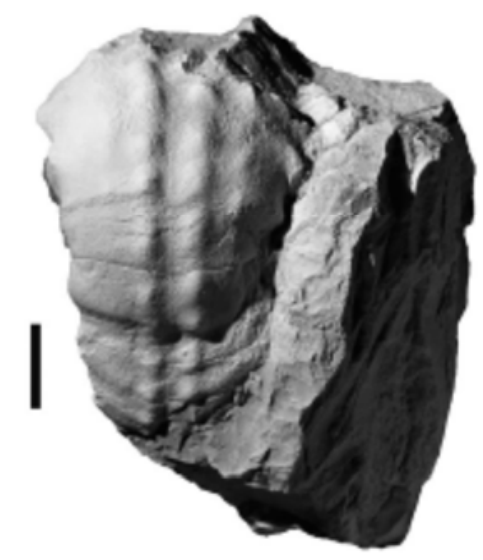

D
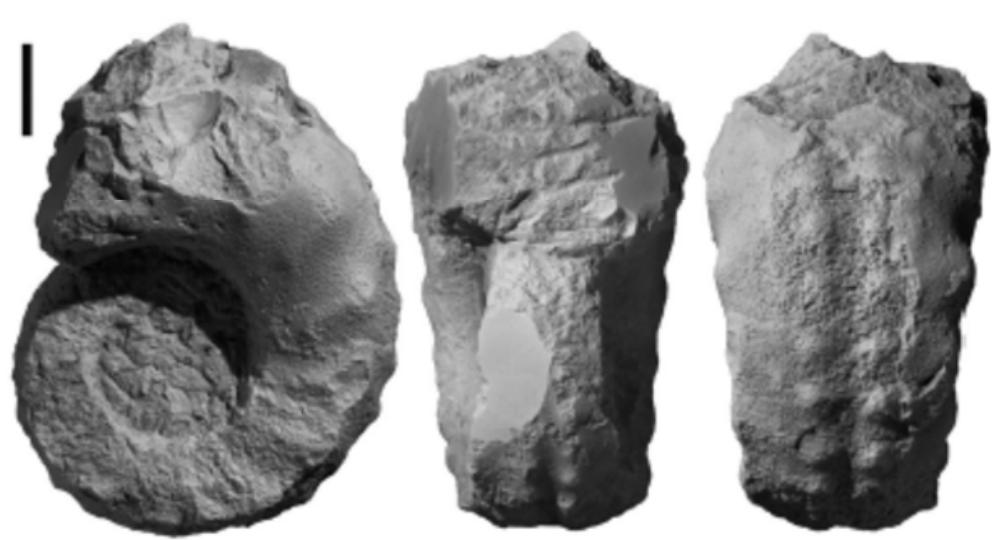

E 
FIG. 6. Neotainoceras sp. B from Gujiao (Guizhou), YFMCUG 00214. Scale bar $=10 \mathrm{~mm}$.
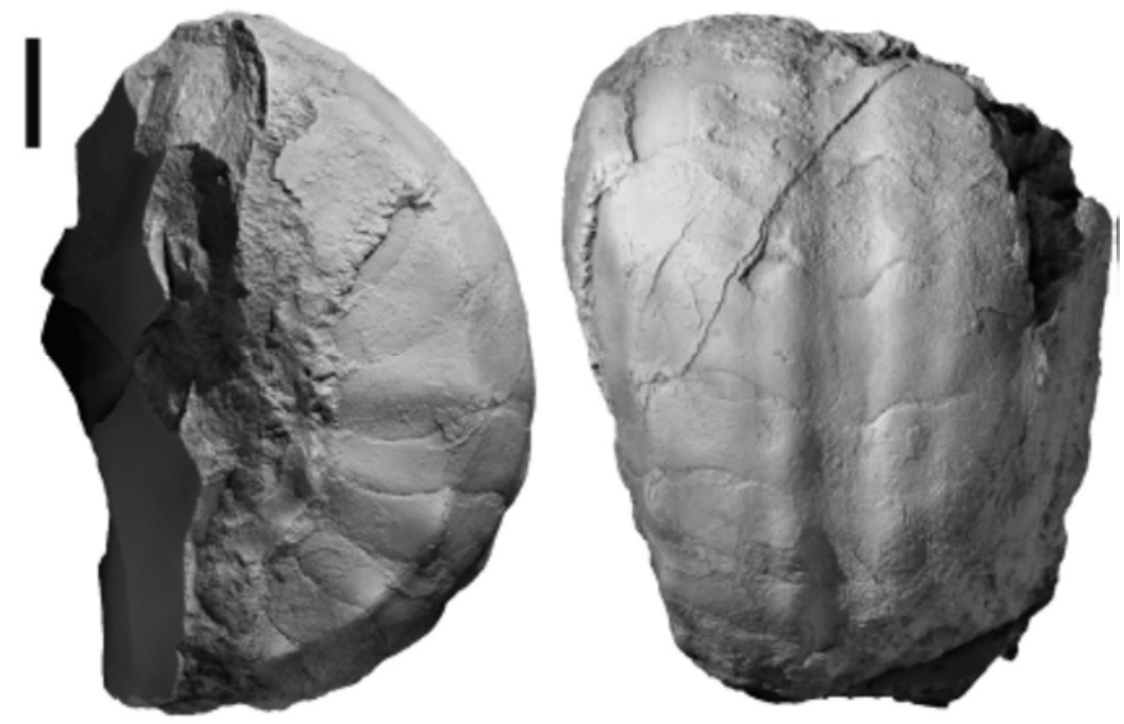
FIG. 7. A-B, Pleuronautilus zhongyingensis (Zheng, 1984) from Gujiao (Guizhou). A, YFMCUG 00215. B, YFMCUG 00216. C-G, Pleuronautilus sp. from Gujiao (Guizhou). C, YFMCUG 00218. E, YFMCUG 00219. D, suture line of YFMCUG 00219, at wh = $20.6 \mathrm{~mm}$. G, YFMCUG 00220. F, suture line of YFMCUG 00220, at $\mathrm{wh}=10.9 \mathrm{~mm}$. Scale bars $=10 \mathrm{~mm}$. 


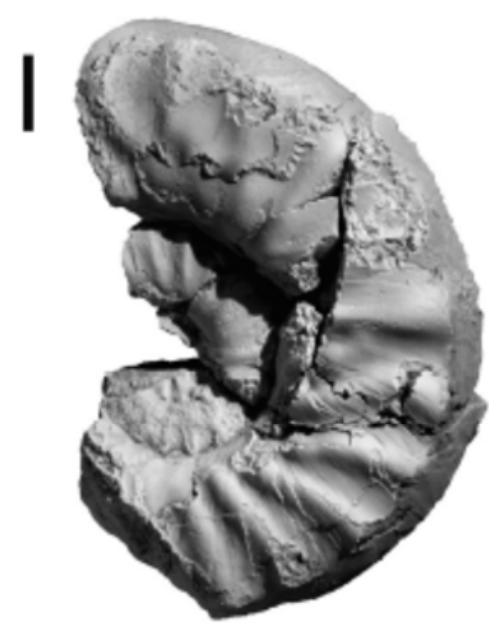

A

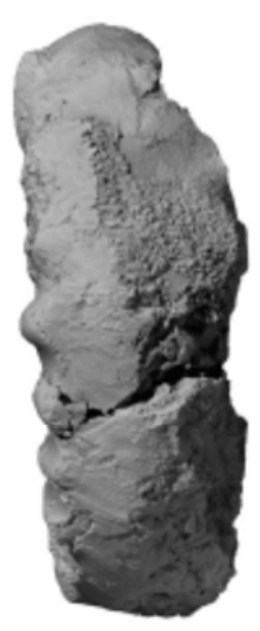

A

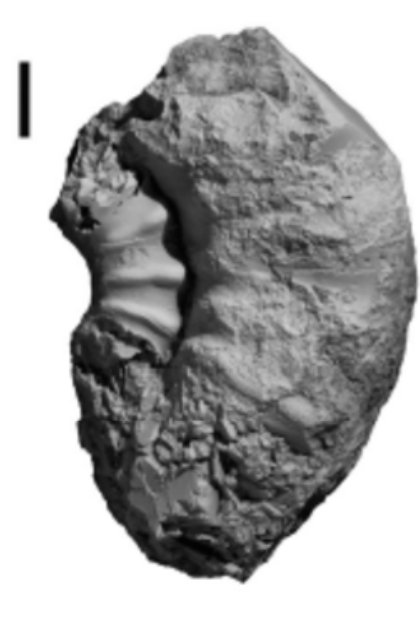

B

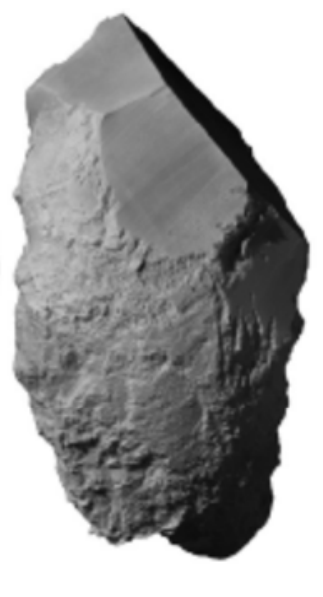

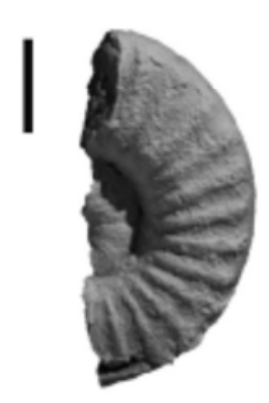
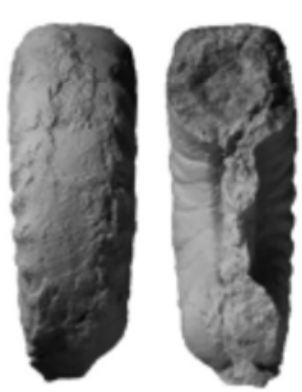

C
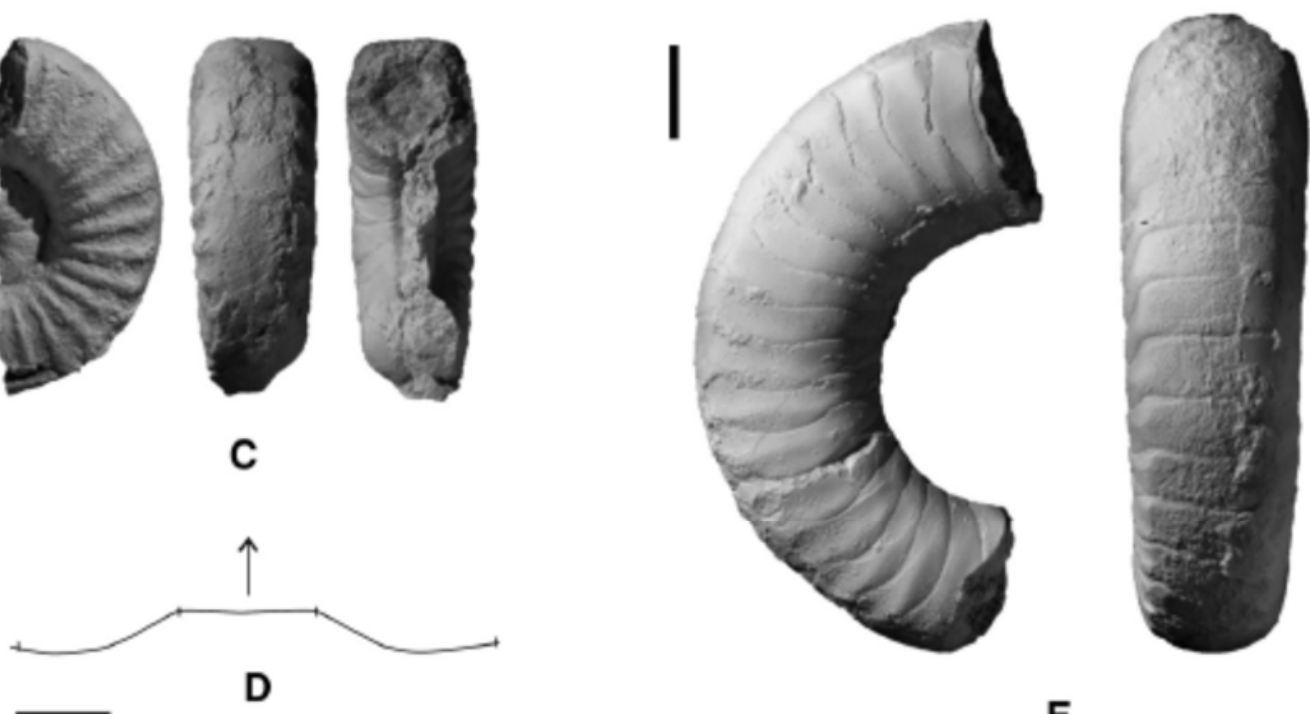

E
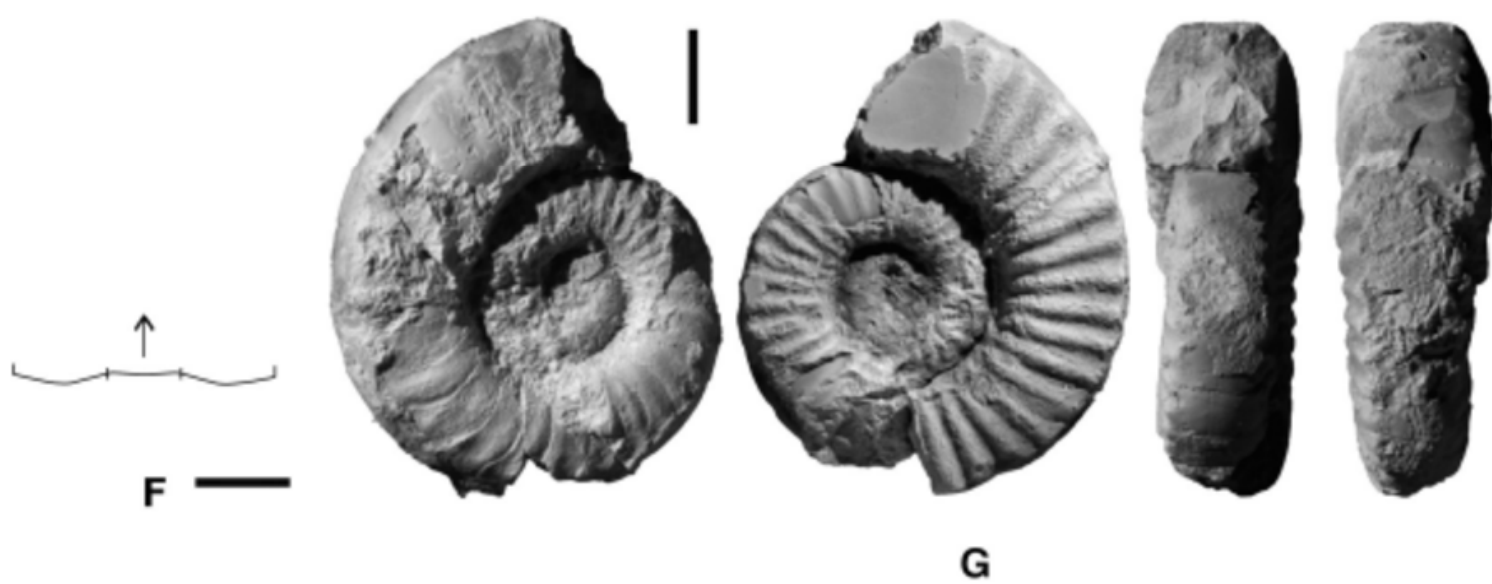

G 
FIG. 8. A-D, Nodopleuroceras gujiaoense sp. nov. from Gujiao (Guizhou). A, YFMCUG 00225 (holotype). B, YFMCUG 00226 (paratype). D, YFMCUG 00227 (paratype). C, suture line of YFMCUG 00227, at wh = $23.2 \mathrm{~mm}$. E-F, Gujiaonautilus longliensis gen. nov., sp. nov. from Gujiao (Guizhou). E, YFMCUG 00242. F, YFMCUG 00243. Scale bars $=10 \mathrm{~mm}$. 


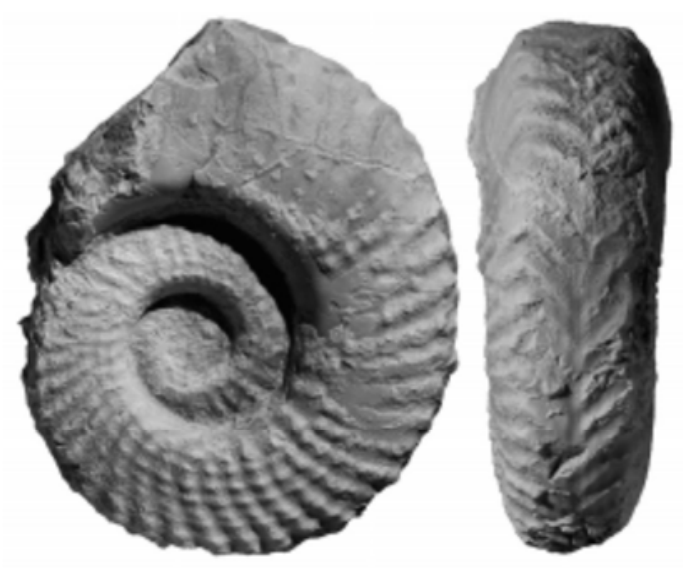

A
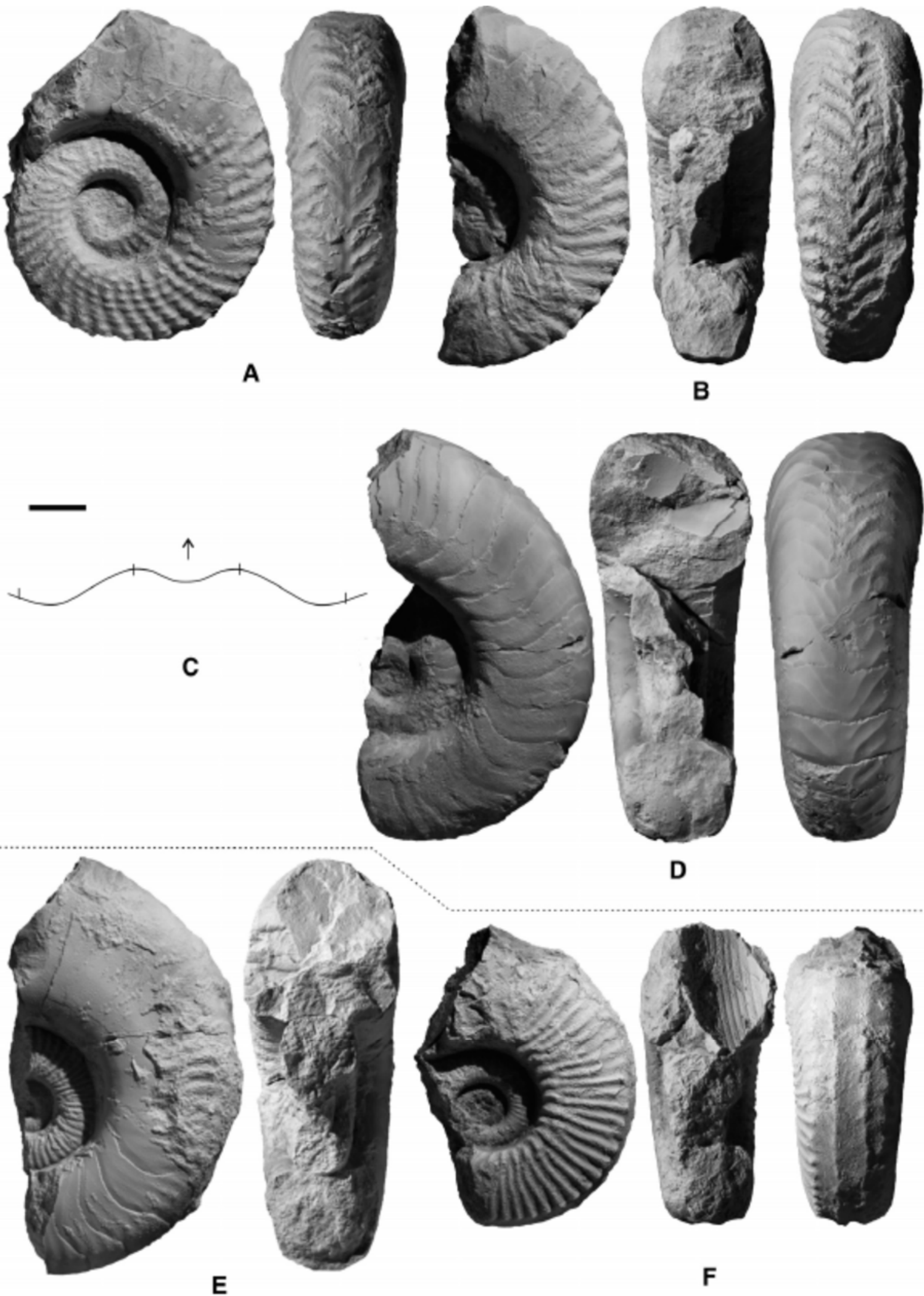

E
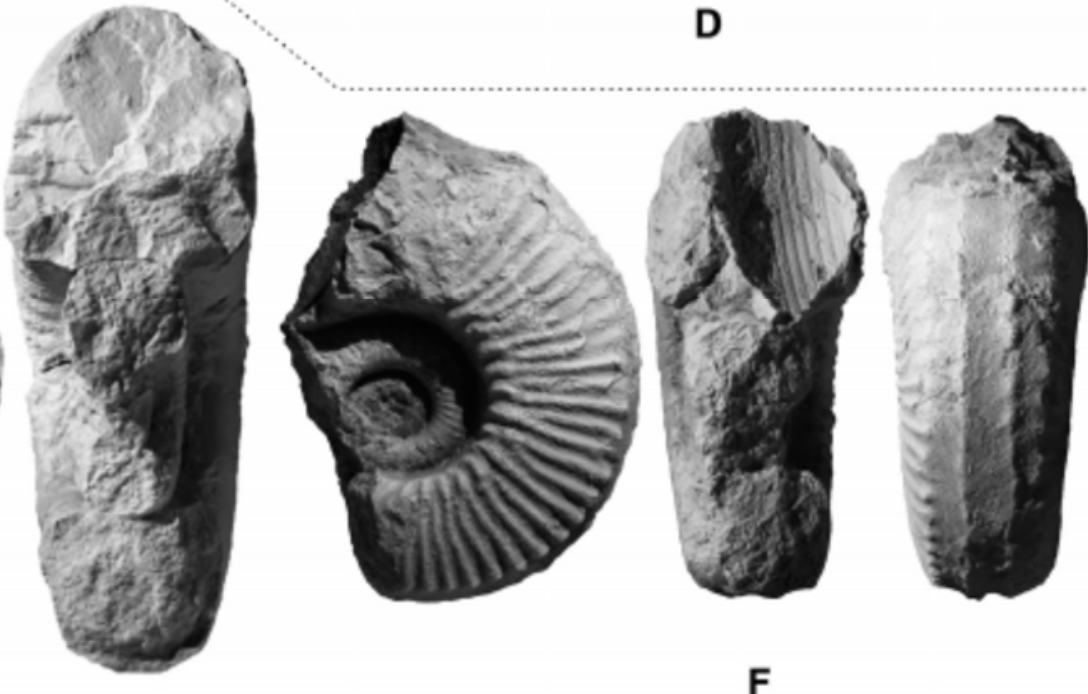

F 
FIG. 9. Gujiaonautilus longliense gen. nov., sp. nov. from Gujiao (Guizhou). A, YFMCUG 00244 (paratype). B, YFMCUG 00245 (paratype). C, suture line of YFMCUG 00245, at wh = $17.2 \mathrm{~mm}$. Scale bars $=10 \mathrm{~mm}$.
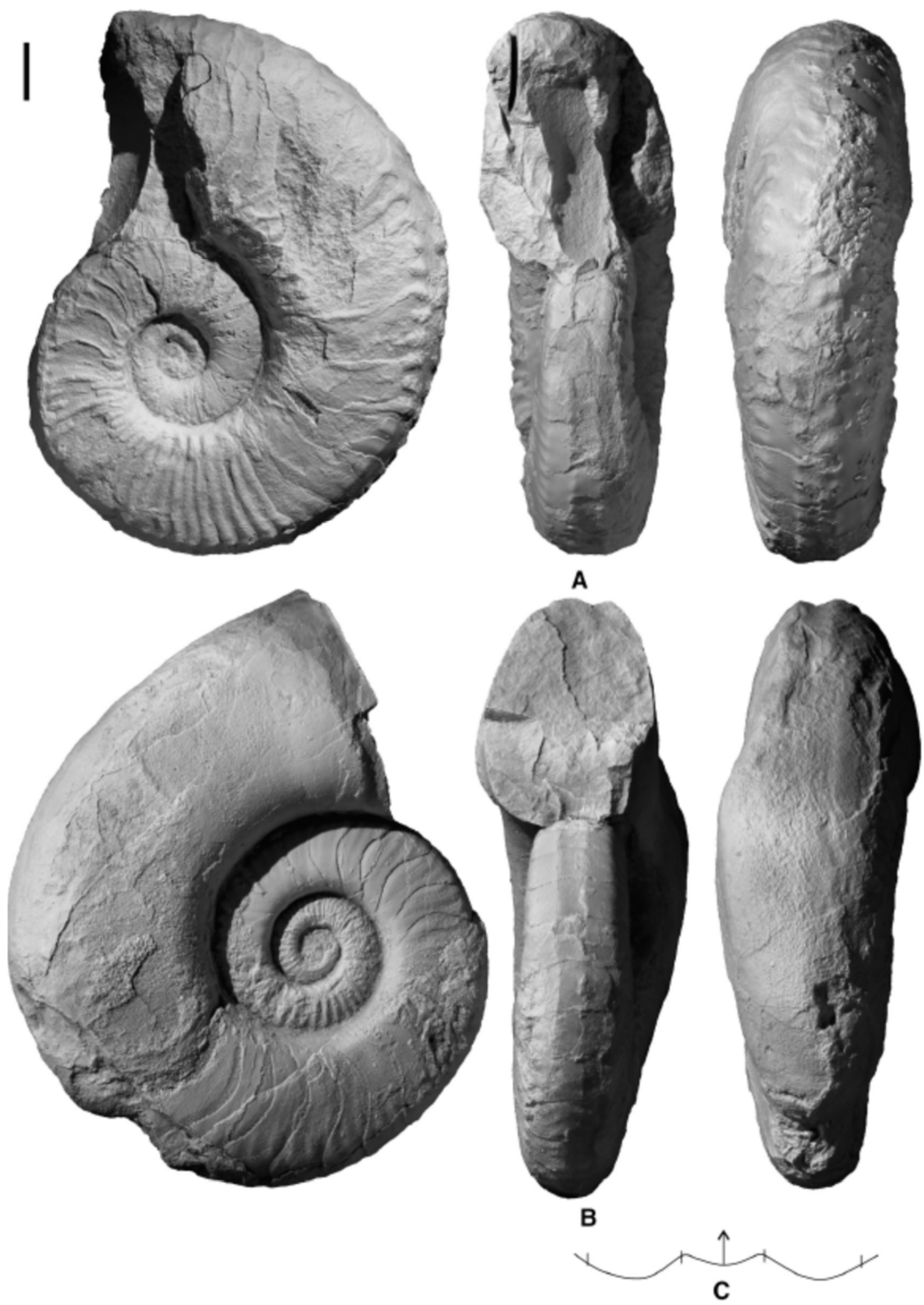
FIG. 10. Gujiaonautilus longliense gen. nov., sp. nov. from Gujiao (Guizhou). A, YFMCUG 00246 (paratype). B, suture line of YFMCUG 00246, at wh $=23.5 \mathrm{~mm}$. C, YFMCUG 00247. D, YFMCUG 00248 (holotype). E, YFMCUG 00249. F, YFMCUG 00250 (paratype). G, YFMCUG 00251. Scale bars $=10 \mathrm{~mm}$.
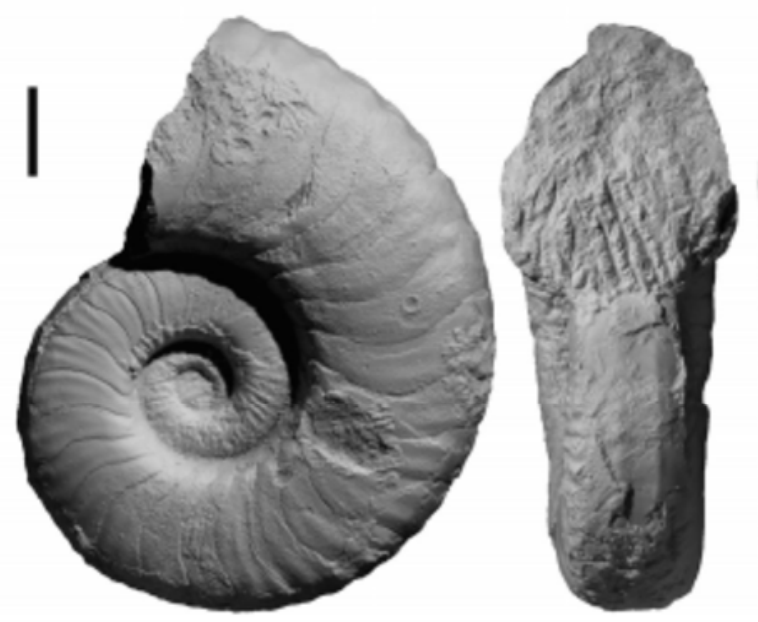

A
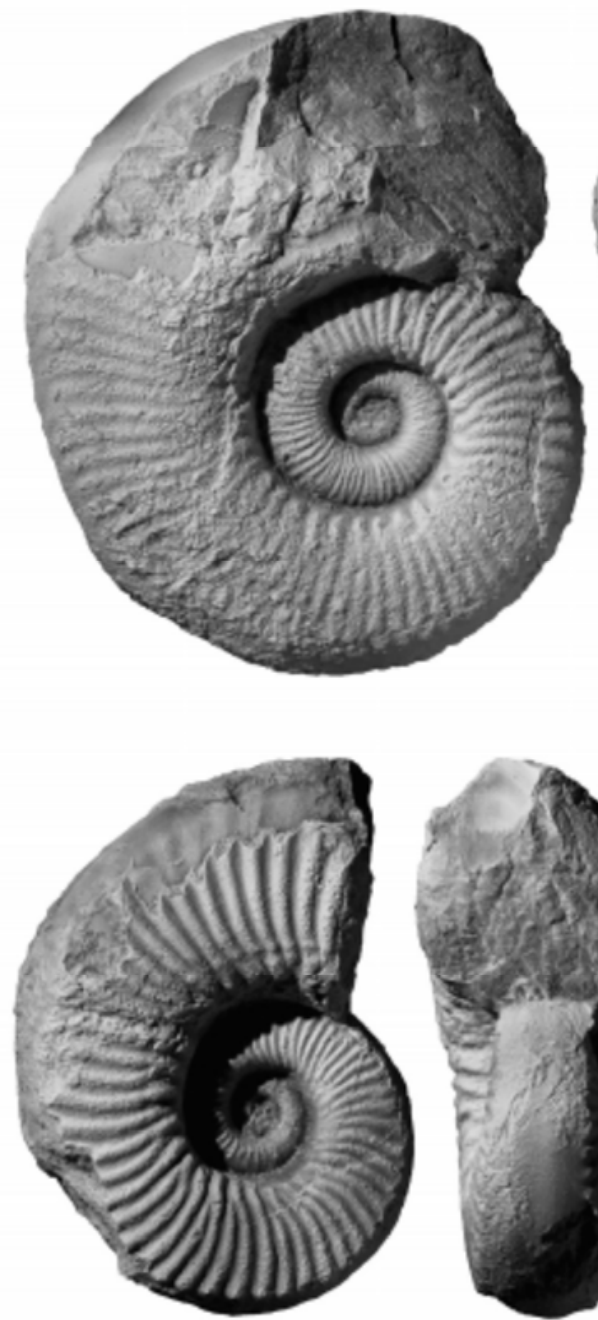
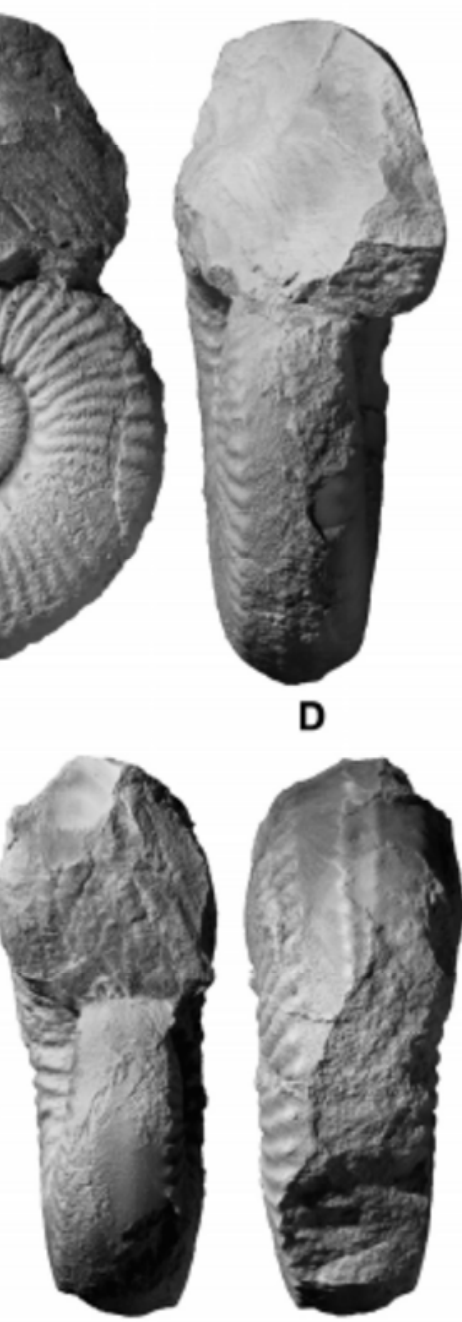

$\mathbf{F}$

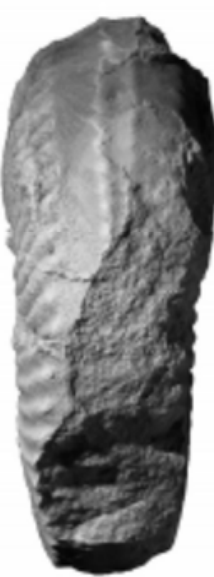

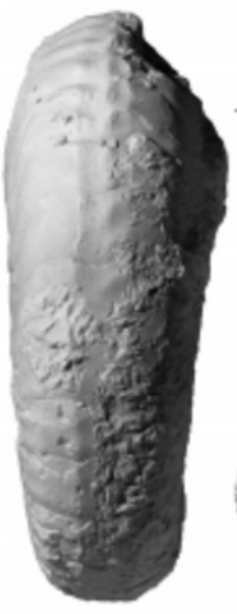
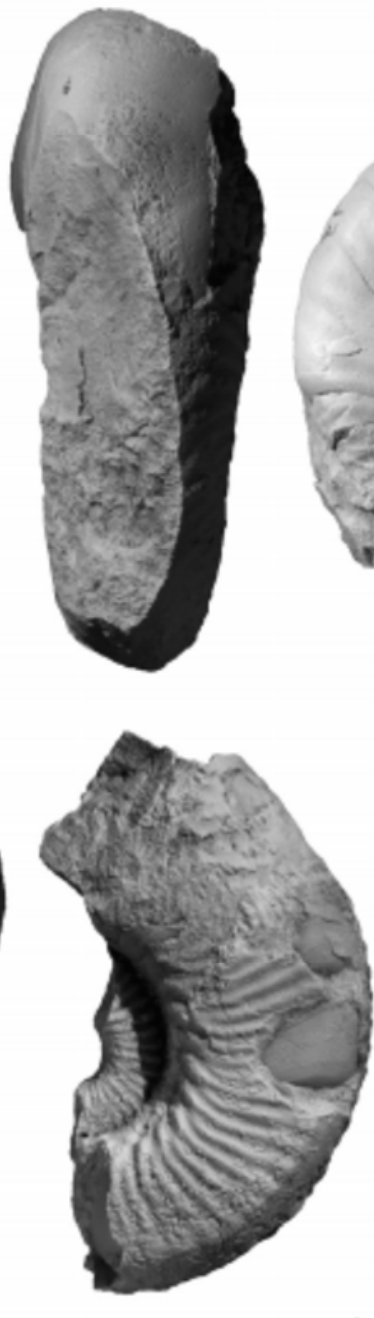

G

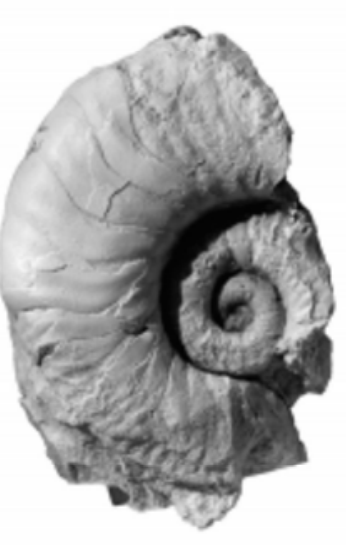

E

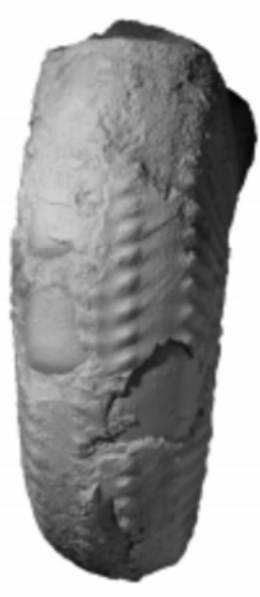


FIG. 11. Scatter diagrams of $H, W$, and $U$ (left), and of $H / D, W / D$, and $U / D$ (right) for

Gujiaonautilus longliense sp. nov. D diameter, $\mathrm{H}$ whorl height, U umbilical diameter, W whorl width.
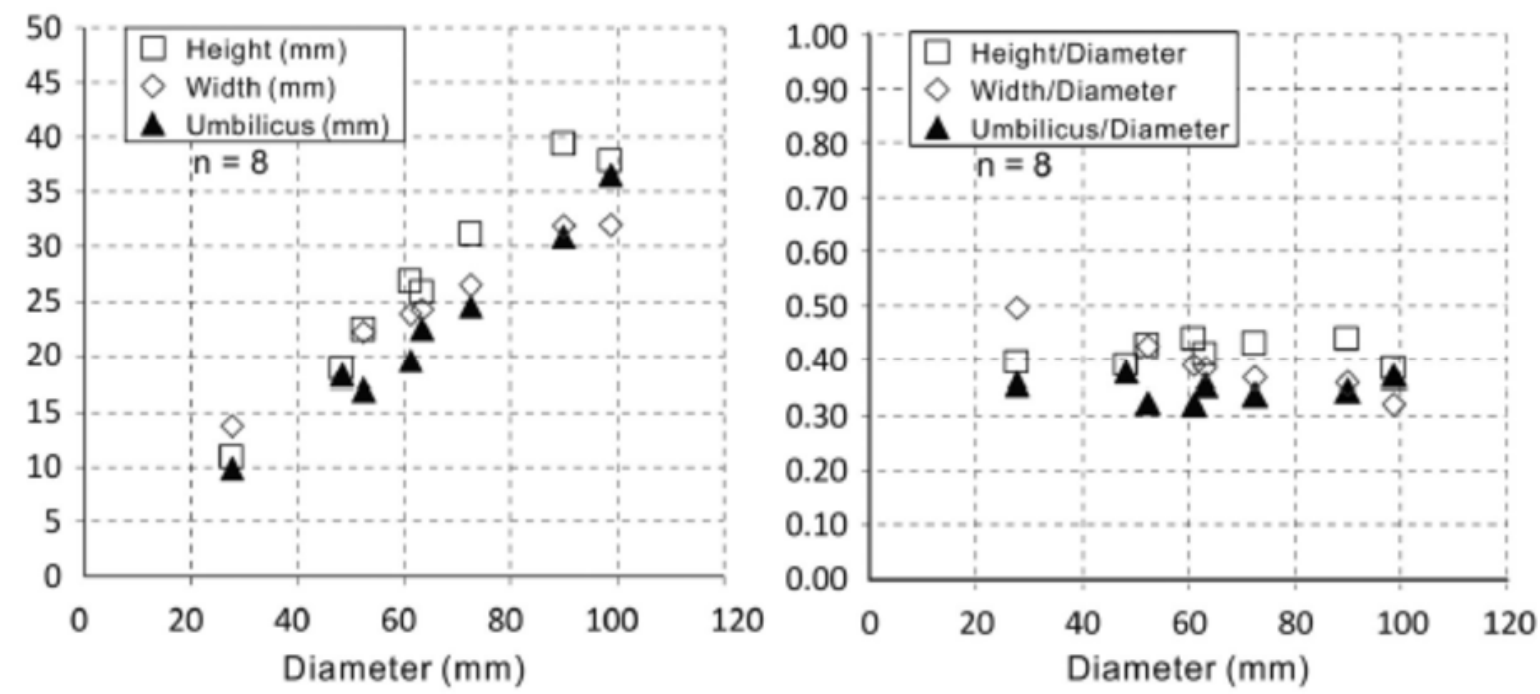

FIG. 12. Sholakoceras sp. from Gujiao (Guizhou). A, YFMCUG 00291. B, suture line of YFMCUG 00291, at wh $=10.4 \mathrm{~mm}$. Scale bars $=10 \mathrm{~mm}$.
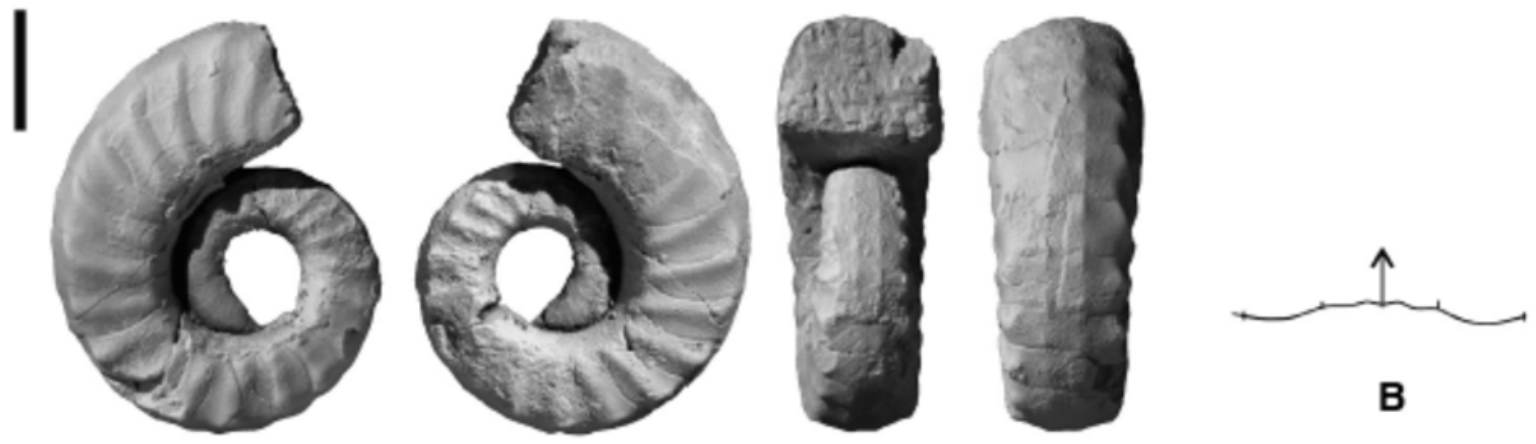
FIG. 13. A-B, Liroceras lichuanense (Wu, 1992) from Gujiao (Guizhou). A, YFMCUG 00292. B, YFMCUG 00293. C, Liroceras orientale (Zhao, 1954) from Gujiao (Guizhou), YFMCUG 00294. Scale bars $=10 \mathrm{~mm}$.
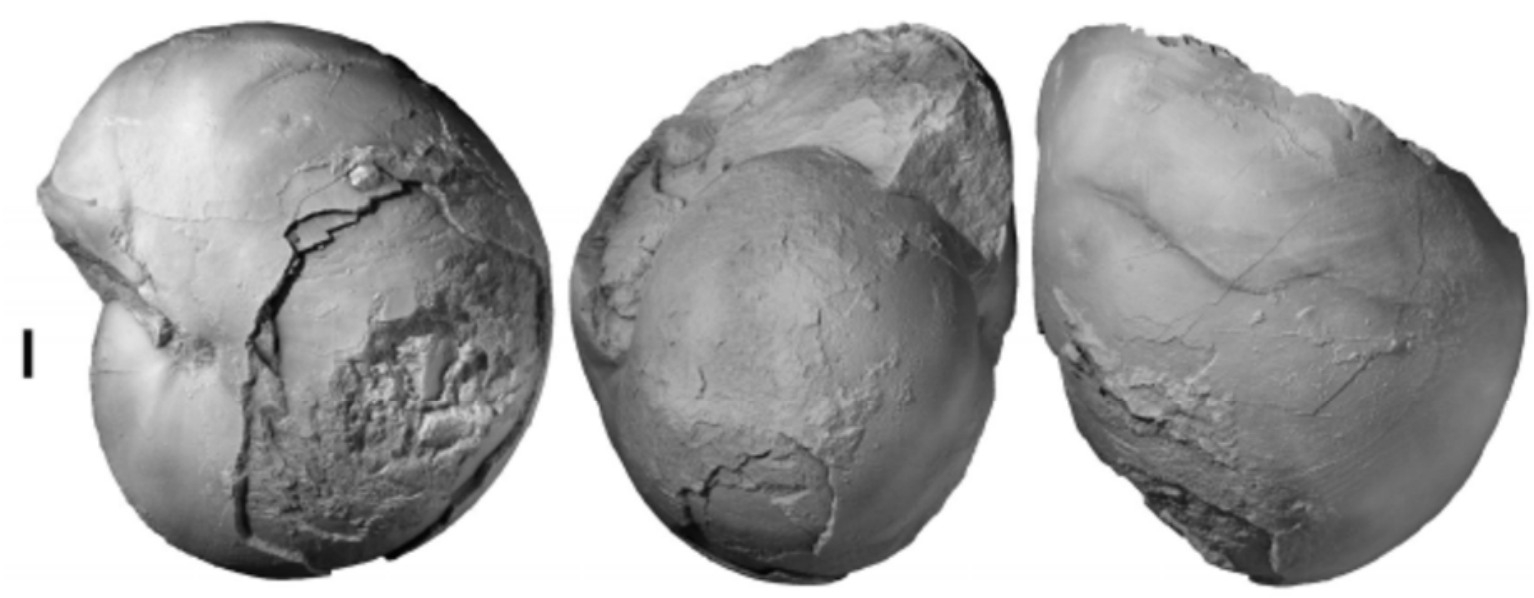

A
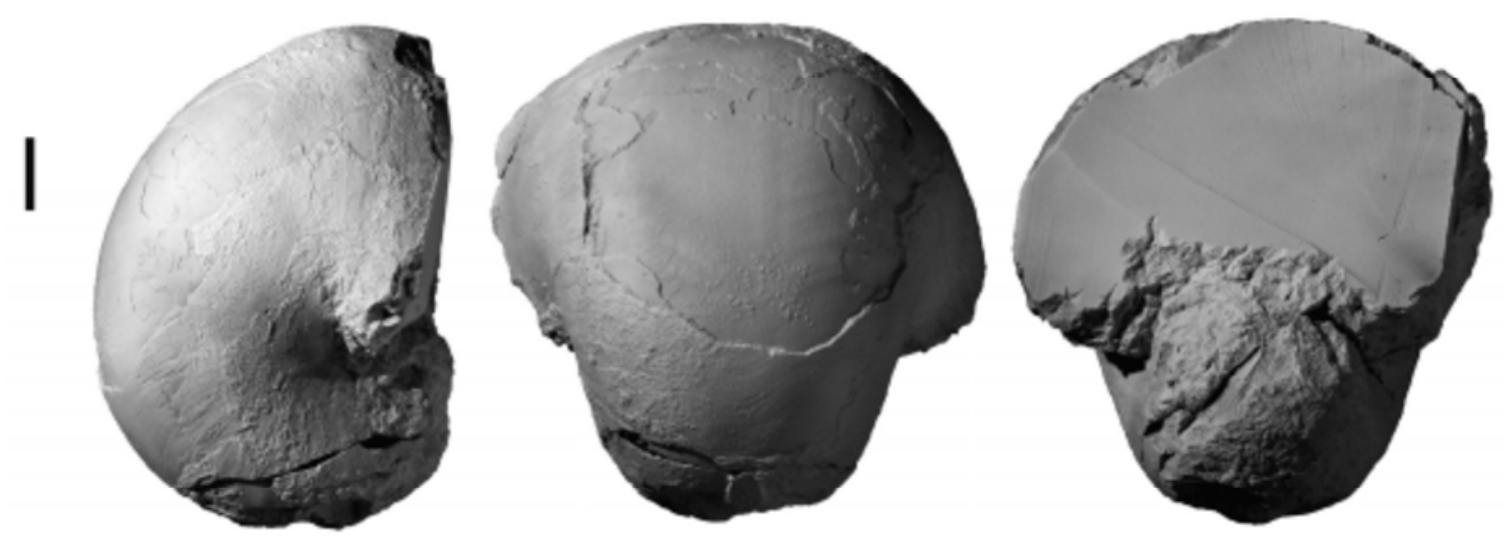

B
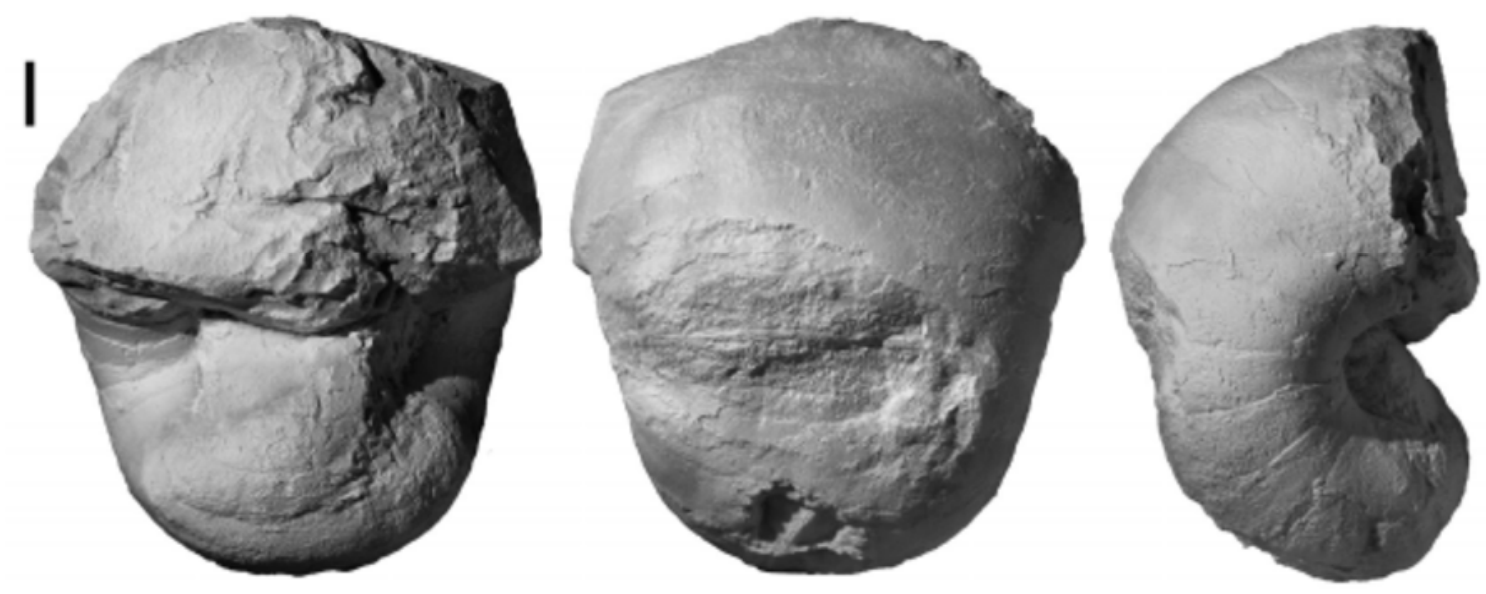

C 
FIG. 14. Liroceras orientale (Zhao, 1954) from Gujiao (Guizhou). A, YFMCUG 00295. B, YFMCUG 00296. C, YFMCUG 00297. Scale bars $=10 \mathrm{~mm}$.
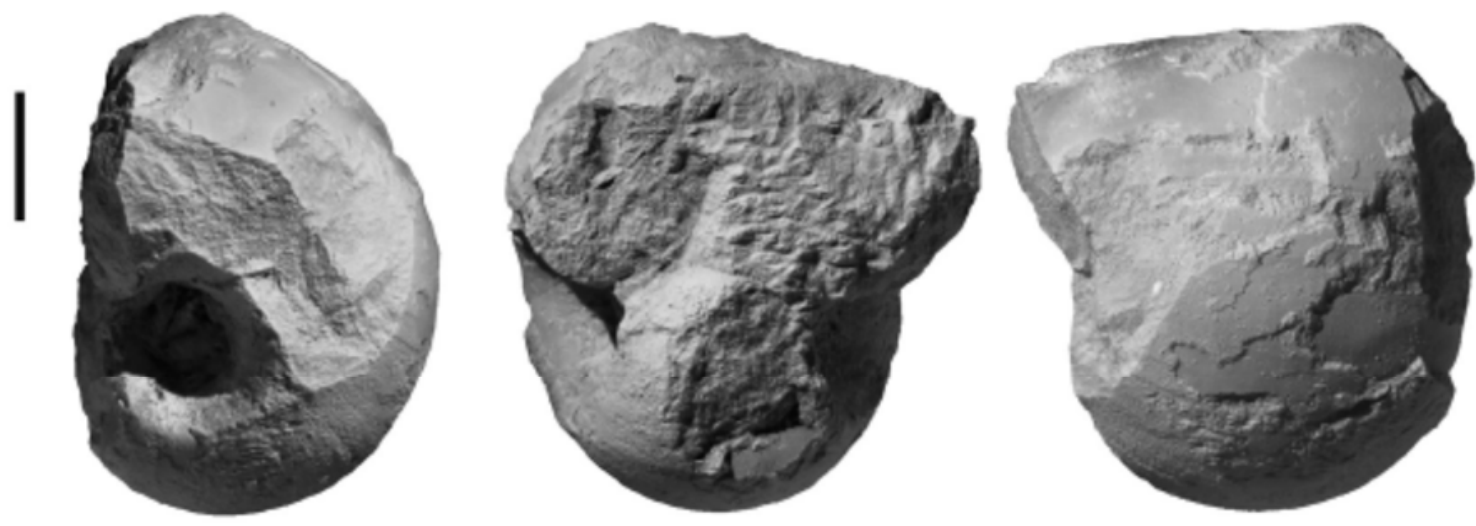

A
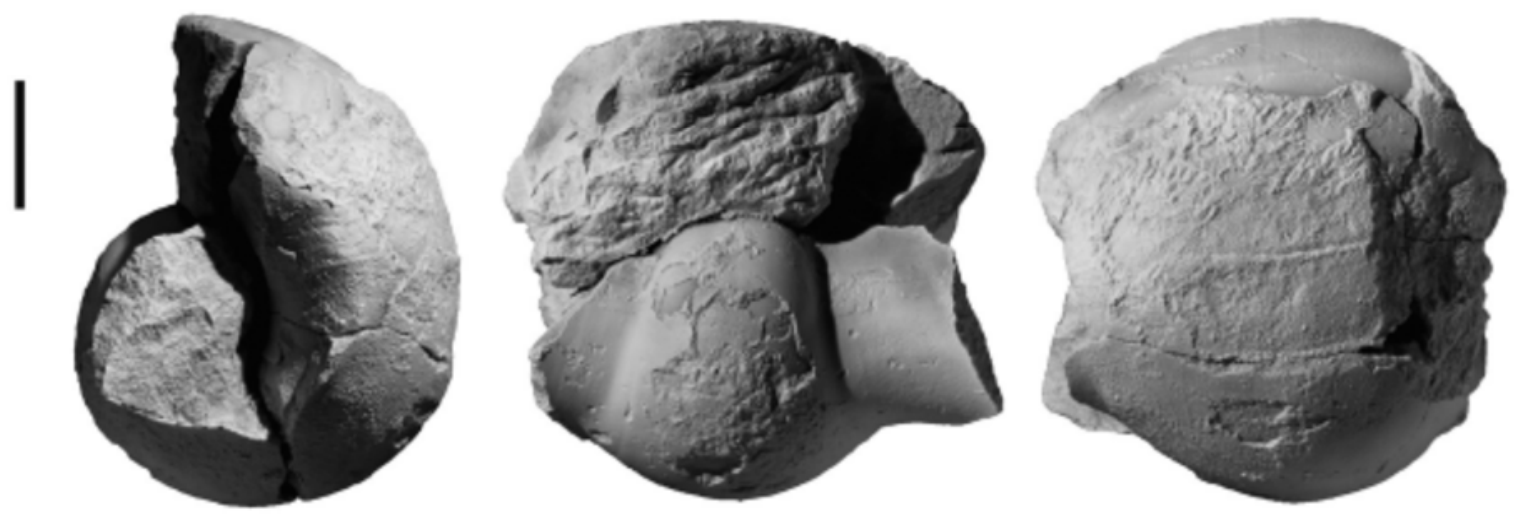

B
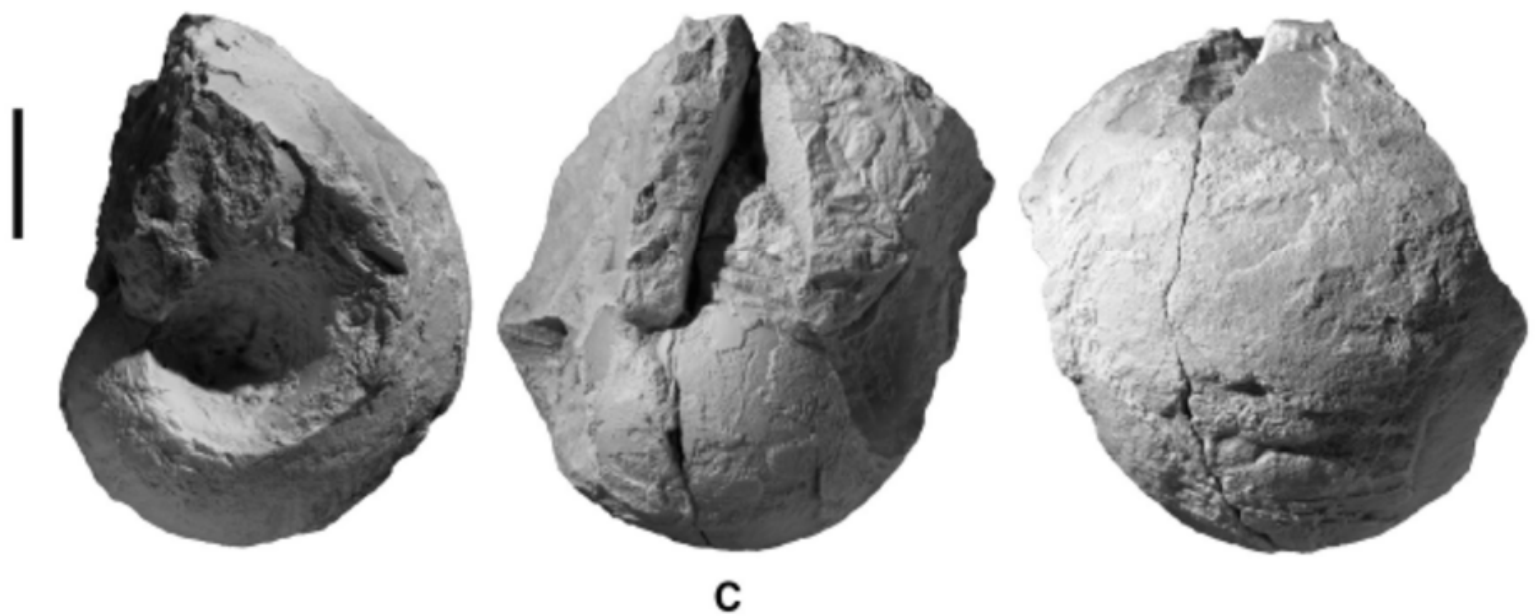

C 
FIG. 15. A-C, Aulagonoceras plicatum (Zheng, 1984) from Gujiao (Guizhou). A, YFMCUG 00300. B, YFMCUG 00299.C, suture line of YFMCUG 00299, at wh $=13.3 \mathrm{~mm}$. D, Pseudotitanoceras sp. from Gujiao (Guizhou), YFMCUG 00301. Scale bars $=10 \mathrm{~mm}$.
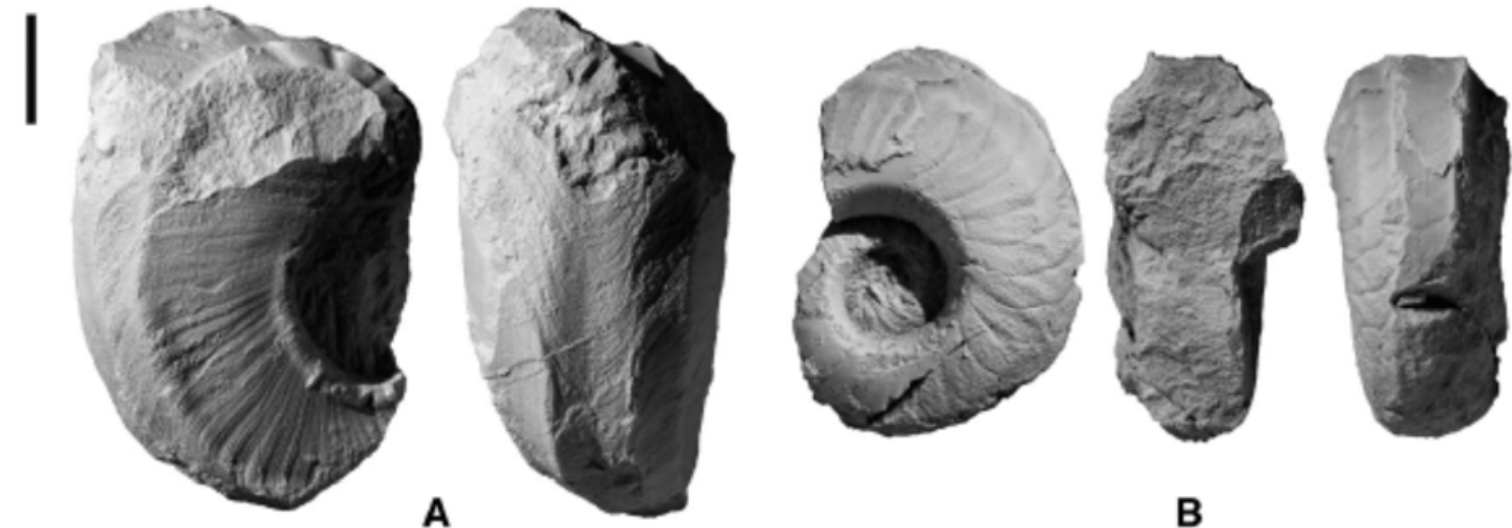

B
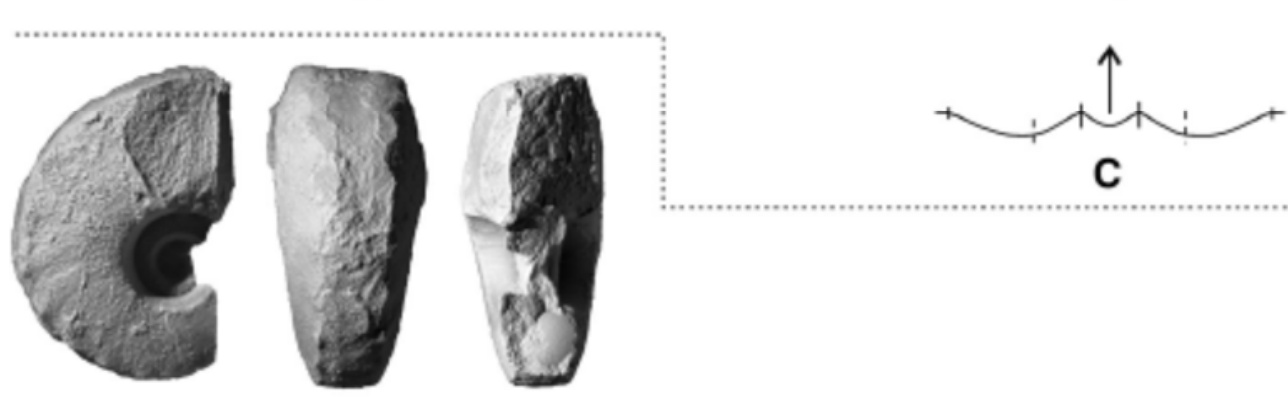

D 